\title{
How might climate change affect river flows across West Africa?
}

\author{
Ponnambalam Rameshwaran ${ }^{1}$ (D) . Victoria A. Bell ${ }^{1}$ (D) - Helen N. Davies ${ }^{1}$ (D) \\ Alison L. Kay ${ }^{1}$ (D)
}

Received: 22 April 2021 / Accepted: 27 October 2021 /Published online: 6 December 2021

(c) The Author(s) 2021

\begin{abstract}
West Africa and its semi-arid Sahelian region are one of the world's most vulnerable regions to climate change with a history of extreme climate variability. There is still considerable uncertainty as to how projected climate change will affect precipitation at local and regional scales and the consequent impact on river flows and water resources across West Africa. Here, we aim to address this uncertainty by configuring a regional-scale hydrological model to West Africa. The model (hydrological modelling framework for West Africa-HMF-WA) simulates spatially consistent river flows on a $0.1^{\circ} \times 0.1^{\circ}$ grid (approximately $10 \mathrm{~km} \times 10 \mathrm{~km}$ ) continuously across the whole domain and includes estimates of anthropogenic water use, wetland inundation, and local hydrological features such as endorheic regions. Regional-scale hydrological simulations driven by observed weather data are assessed against observed flows before undertaking an analysis of the impact of projected future climate scenarios from the CMIP5 on river flows up to the end of the twenty-first century. The results indicate that projected future changes in river flows are highly spatially variable across West Africa, particularly across the Sahelian region where the predicted changes are more pronounced. The study shows that median peak flows are projected to decrease by $23 \%$ in the west (e.g. Senegal) and increase by $80 \%$ in the eastern region (e.g. Chad) by the 2050s. The projected reductions in river flows in western Sahel lead to future droughts and water shortages more likely, while in the eastern Sahel, projected increases lead to future frequent floods.
\end{abstract}

Keywords Climate change $\cdot$ CMIP5 $\cdot$ Hydrological modelling $\cdot$ River flow $\cdot$ Sahel $\cdot$ West Africa

\section{Introduction}

West Africa experiences some of the most devastating precipitation variability anywhere in the world and has a history of prolonged and severe droughts, most notably the semi-arid Sahelian region (Taylor et al. 2017; Vischel et al. 2019). There are growing signs that the

Ponnambalam Rameshwaran ponr@ceh.ac.uk

1 UK Centre for Ecology \& Hydrology, Wallingford OX10 8BB, Oxfordshire, UK 
long-term climate across West Africa is changing particularly in the seasonal cycle and the decadal variability of the rainfall regime (IPCC, 2014; Lebel and Ali 2009), potentially leading to more frequent extreme hydrological situations-floods as well as droughts (Bichet and Diedhiou 2018; Chagnaud et al. 2021; Panthou et al. 2018; Tazen et al. 2019; Wilcox et al. 2018).

The local impact of projected climate change on water resources and flooding is critical to the lives and livelihoods of people living in West Africa. The spatial and temporal variability of water availability is an ongoing challenge for development activities across the region. Agriculture is the largest economic sector, and the region is heavily dependent on surface sources for the fresh water supply. Hydropower is becoming the primary source of energy due to fast economic growth along with population growth and urbanisation (Obeng-Ofori 2018). The potential impacts of climate change could include substantial stresses on the agricultural sector, on the management of fresh water resources, development activities, and on ecosystem management. These potential impacts affect a region that is already under considerable stress due to extreme climate variability. Projected climate change could increase the frequency and intensity of drought and could in turn lead to famine, health issues, migration, and social unrest. A sound understanding of the potential effects of climate change on hydrology and water resources across West Africa is vital for local policy-makers and planners in each country. In response to this requirement, we present an assessment of regional-scale hydrological impacts of projected climate change, complementary to other studies evaluating climate impacts on land-atmosphere feedback mechanisms (Boone et al. 2009).

The critical factor defining the overall impact of climate change in this region is precipitation, but predicting changes to its spatial and temporal variability across West Africa is a challenge. At present, most of the current global or regional climate models represent Earth system atmospheric processes to spatial scales of 10 to $100 \mathrm{~km}$ at a daily time step, but they are incapable of capturing more-localised, intense rainfall events (Dosio and Panitz 2016). Although the majority of climate modelling studies are in broad agreement when it comes to predicting climate change impacts on long-term weather patterns across West Africa, there are fewer agreements on high-resolution predictions. Only very recently, Kendon et al. (2019) applied a convection-permitting model (4.5 km grid resolution) over an Africa-wide domain (CP4A) in order to realistically capture hourly precipitation characteristics. Their analysis indicated future increases in dry spell length during the wet season over western and central Africa, and more intense 3-hourly precipitation, than lower-resolution $25 \mathrm{~km}$ regional climate models had previously indicated.

The research presented here was undertaken as part of the African Monsoon Multidisciplinary Analysis 2050 (AMMA-2050) project, which aimed to understand both how extreme weather events will change in the future and their impact on water resources and flooding at the regional scale. Other authors such as Blanchet et al. (2018), Diedhiou et al. (2018), Panthou et al. (2018), Taylor et al. (2017), and Todzo et al. (2020) have investigated the past and projected future impact of the global warming on extreme events and their frequency over West Africa but concentrated on meteorological impacts. The aims of the work presented here are (i) to develop an effective spatially distributed hydrological model for West Africa and (ii) to assess the hydrological impact of projected future changes in extreme weather spatially over the whole domain. To achieve these aims, we have developed and applied a single spatially distributed hydrological model at a $10 \mathrm{~km} \times 10 \mathrm{~km}$ resolution across West Africa (Section 3). The model takes account of anthropogenic water use and other hydrological influences such as endorheic rivers and wetlands. The performance of the model has been assessed using observed daily river flows at gauging stations across 
the region (Section 4), prior to its use to explore the impact of climate change on river flows across the region (Section 5). Data from both bias-corrected and un-corrected CMIP5 (Coupled Model Inter-comparison Project Phase 5) regional climate models have been used to estimate the projected impact of climate change on extreme hydrological events to the end of the twenty-first century for countries across West Africa. Figure 1 presents a schematic of the methodology used, highlighting the three main stages of the hydrological modelling work.

\section{Background: geography and hydrology of West Africa}

West Africa's varied geography encompasses multiple climatic zones: hyper-arid, arid, semi-arid, and dry sub-humid zones where the four major river basins Senegal, Volta, Niger, and Chad are located (Fig. 2a). The longest and largest river in West Africa is the Niger, which crosses 10 countries and has a length of approximately 4,200 km and a catchment area of $2.27 \times 10^{6} \mathrm{~km}^{2}$. The Niger flows through six varied hydrographic regions with distinctive topographic and drainage characteristics (Golitzen et al. 2005), namely (a) Upper Niger, (b) Niger River Inland Delta and Lakes District, (c) Middle Niger RightBank Tributaries, (c) Middle Niger Left-Bank Tributaries (d), Lower Niger River, and (e) Niger Delta, also shown in Fig. 2a. In the Niger River Inland Delta and Lakes District, the vast wetland (Fig. $2 b$ and c) attenuates a considerable volume of incoming river flow through infiltration, retention, and evaporation which greatly reduces runoff in the region (Golitzen et al. 2005).

However, several tributaries in the sandy Middle Niger Left-Bank are part of the wadi network. These tributaries contribute mostly little or no flow to the main Niger River and are considered endorheic basins, as high evaporation or infiltration into the subsurface results in little or no runoff and river flow (shaded areas in Fig. 2b). These endorheic regions reduce the area of the Niger River catchment by almost half $\left(1.1\right.$ to $\left.1.5 \times 10^{6} \mathrm{~km}^{2}\right)$ which can be considered hydrologically active (Descroix et al. 2009; Golitzen et al. 2005).

The Sahel experienced major droughts during the 1970s and 1980s, and the region's land use changed substantially (Biasutti 2019; Nicholson 2013) leading to the development of crusted soil areas (Amogu et al. 2015). However, river flows have unexpectedly increased in some areas, particularly in recent decades. This apparent paradox was first observed in Burkina Faso by Albergel (1987) and later confirmed for the Middle Niger River by Mahé and Olivry (1999), Olivry (2002), and Amani and Nguetora (2002). The

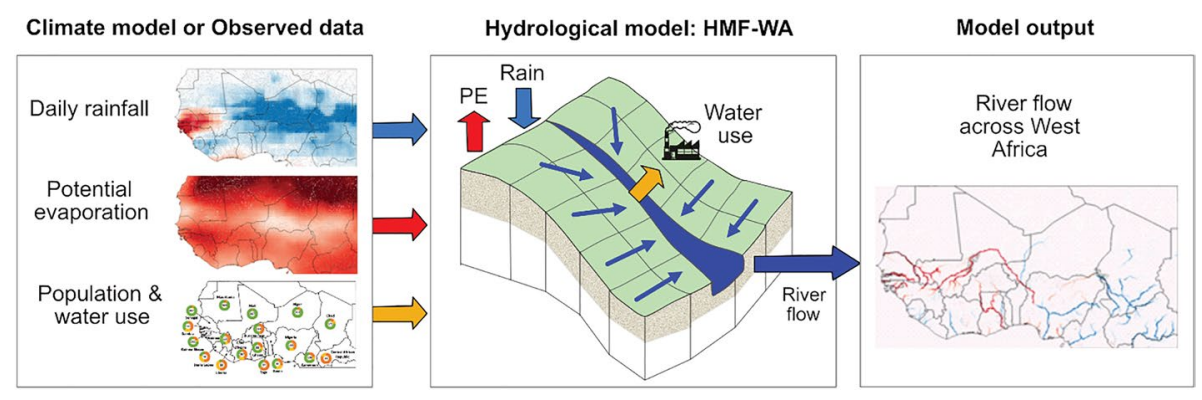

Fig. 1 Schematic of the methodology used within the hydrological model 
(a)

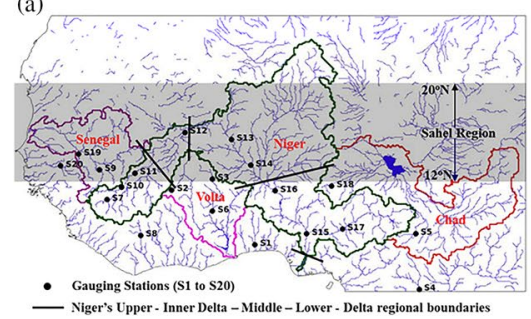

(c)

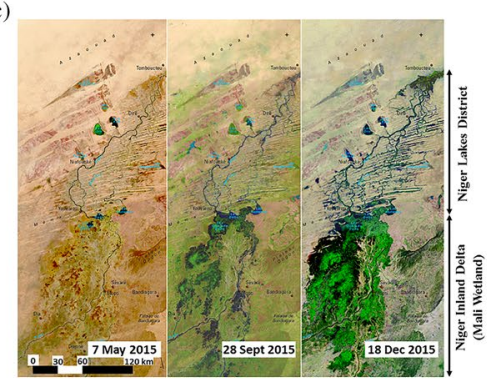

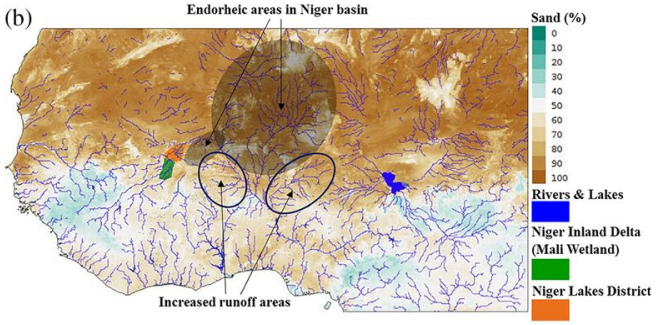

(d)

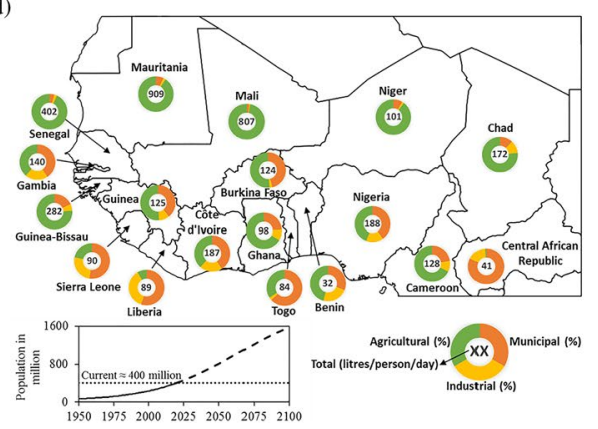

Fig. 2 Maps of West Africa showing a major river basins and the Sahel region, including Niger River hydrographic regions and gauging station locations; b soil texture (\% sand) and endorheic and increased runoff areas; c Seasonal changes in the Niger River Inland Delta (Mali Wetland) and Lakes District (https:// eros.usgs.gov/westafrica/case-study/landscape-diversity-and-dynamics-inland-niger-delta), shown with green and orange shading in Fig. $2 \mathbf{b}$; $\mathbf{d}$ current total water usage by the country (litres/person/day) and percentage by sector (municipal, industrial, and agricultural) from AQUASTAT database (FAO 2016) and (inset) time series of historical and projected population of West Africa from 1950 to 2100 (UN 2017)

extent of the affected region is circled in Fig. 2b (Descroix et al. 2013). In addition, the water table in the endorheic areas has raised due to excess of runoff leading to an increased number of ponds which would otherwise have replenished deep infiltration and groundwater recharge (Descroix et al. 2013; Gardelle et al. 2010; Leduc et al. 2001). These poorly understood regional behaviours are collectively known as the "Sahelian Paradox" in the literature and are thought to be linked to significant recent land use change which has impacted on soil characteristics and led to increased surface runoff (Amogu et al. 2010). These changes are thought to have increased the likelihood of flooding in Sahelian areas during extreme wet weather conditions.

\section{Methods: data and hydrological modelling with HMF}

\subsection{Model formulation}

Various hydrological models have been developed to simulate river flows in catchments or sub-regions across West Africa, but very few have modelled the whole region at once with a spatially distributed formulation. Niel et al. (2003) undertook catchment-based hydrological modelling with a monthly time step for 17 river basins from West and Central African regions to study parameter stability respects to 
climatic variability. Several authors have applied semi-distributed models; for example Dezetter et al. (2008) and Paturel et al. (2003) studied the influence of distributed driving data for West African catchments, and Thompson et al. (2017) modelled the Upper Niger and the Inner Niger Delta to investigate the impact of the RCP4.5 climate scenario for 41 CMIP5 GCMs in the 2050s and 2080s. Andersen et al. (2001) implemented and validated the physically based distributed MIKE SHE hydrological model to the Senegal River catchment. More recently, Kwakye and Bárdossy (2020) used the conceptual HBV hydrological model on the data-scarce catchment Black Volta to investigate the performance, and Boko et al. (2020) applied the fully integrated surface-subsurface HydroGeoSphere model on the semi-arid urban watershed in the Niamey Republic of Niger. In this study, a grid-based, spatially distributed hydrological model (HMF-WA) has been adapted to simulate river flows on a $0.1^{\circ} \times 0.1^{\circ}$ grid (approximately $10 \mathrm{~km} \times 10 \mathrm{~km}$ ) across West Africa. The spatially distributed formulation has been adopted in order to understand the regional impact of climate change in a spatially consistent way across countries and catchments. The approach provides a means to quantify change in projected river flows for policy-makers and can potentially highlight vulnerable regions and countries.

The hydrological modelling framework (HMF) (Crooks et al 2014) provides a gridbased, spatially distributed hydrological modelling framework which is similar in structure to the G2G model (Bell et al. 2007). The HMF is modular and enables the user to link a chosen grid-based runoff-production scheme with a kinematic wave (KW) flow routing scheme to estimate river flows on a regular grid across wide areas (for catchments, regions, or global application). It contains a series of modules that provide model set-up, input of gridded driving data, production of gridded runoff, KW routing along a network of flow paths to estimate river flows, and output of gridded model variables such as runoff, soil moisture, and river flow. The HMF for West Africa, or "HMF-WA", is implemented at a $0.1^{\circ} \times 0.1^{\circ}$ grid (approximately $10 \mathrm{~km} \times 10 \mathrm{~km}$ ) with the domain of latitudes $3^{\circ}$ to $26^{\circ} \mathrm{N}$ and longitudes $-18^{\circ}$ to $25^{\circ} \mathrm{E}$ (Fig. 2) and has been enhanced to include hydrological processes important in the region such as wetlands, anthropogenic water use, and endorheic rivers.

The HMF-WA runoff-production scheme is grid-based and assumes a vertically integrated representation of soil moisture in each grid box, similar to that used in the gridto-grid (Bell et al. 2007). The model requires driving data consisting of spatial grids of daily rainfall and potential evaporation (PE) and maintains a continuous soil moisture store which receives water through rainfall excess (rainfall - actual evaporation), and loses water from surface runoff following a rainfall event, and through soil drainage to subsurface storage and runoff. Here, soil texture data are used to parameterise VanGenuchten-derived estimates of soil hydraulic conductivity and saturated and residual soil moisture values in each grid cell. In order to represent the spatial heterogeneity of a $0.1^{\circ} \times 0.1^{\circ}$ soil column to rainfall, a probability distribution of soil moisture storage is assumed (Moore 2007).

The routing module used in HMF-WA is based on a KW scheme (Bell et al. 2007) and allows for parallel routing of surface and subsurface runoff. Each (non-sea) grid box is designated as either "land" or "river" using a cumulative catchment area threshold of 5 grid cells. Thus, four wave speeds are defined (for river channel and river subsurface, land surface, land subsurface), with slower wave speeds for land and subsurface routing. A return flow term allows for water transfer between subsurface and surface routing stores and typically provides the base-flow component of the hydrograph. 
The KW model equation in $1 \mathrm{D}$ is as follows:

$$
\frac{\partial Q}{\partial t}+c \frac{\partial Q}{\partial x}=c(u+R)
$$

where $Q$ is surface or subsurface flow $\left(\mathrm{m}^{3} \mathrm{~s}^{-1}\right), R$ denotes return flow per unit path length (water transfer between subsurface and surface pathways), and $u$ represents lateral inflows per unit path length, which include runoff generated by the runoff-production scheme. The wave speed (celerity) $c$ can vary with the pathway (surface or subsurface) and surface-type (land or river) combination. In practice, a forward difference approximation (Jones and Moore 1980) to the derivatives in Eq. (1) is applied (Bell et al. 2007) with a dimensionless wave speed $\theta=c \Delta t / \Delta x$ and $(0<\theta<1)$. For the HMF-WA application, $\Delta x \cong 10 \mathrm{~km}$, and the routing model time step of $\Delta t=4 \mathrm{~h}$ is selected for stability.

For application to the hydrological conditions of West Africa, several empirically derived changes have been made to the HMF-WA model formulation:

i. The standard HMF routing scheme (1) does not explicitly represent inundated areas such as wetlands and lakes and effectively assumes they are rivers. A simple empirical representation of water bodies (e.g. within Niger River Inland Delta and Lakes District) has been introduced to allow for losses in inundated areas by infiltration of water into soil and retention of the river flow and its subsequent losses due to open water evaporation. Specifically, in grid cells with significant water bodies identified from the Niger River Inland Delta and Lakes District (Fig. 2b and c) and the HydroLAKES database (Messager et al. 2016), a constant proportion of river flow is lost at each time step:

$E_{\text {loss }}= \begin{cases}\alpha_{w} Q, & \text { Niger Inland Delta (Mali Wetland) } \\ \alpha_{l} Q, & \text { Niger Lakes District and Other Lakes } \\ 0, & \text { Rivers without Water bodies }\end{cases}$

where $\alpha_{w}(=0.04)$ and $\alpha_{l}(=0.01)$ are the empirically derived wetland and lake loss factors which gave best comparable outflows through these water bodies. The dependence of losses on flow, $Q$, implicitly takes account of the seasonal variation of flow in water bodies.

ii. In endorheic regions (shown in Fig. 2b), deep infiltration of water and enhanced groundwater recharge tends to occur in areas with the highest percentage of sandy soils $(>70 \%)$, while enhanced discharge occurs in areas with a lower percentage of sandy soils. In order to accommodate all situations, the previously constant return flow term, $R$, has been expressed as a spatially varying function $\left(R_{v}\right)$ of soil sand texture as follows:

$$
R_{v}= \begin{cases}0.05, & P_{\text {sand }}<30 \\ 0.05\left(70-P_{\text {sand }}\right) / 40, & 30 \leq P_{\text {sand }} \leq 70 \\ 0, & P_{\text {sand }}>70\end{cases}
$$

where $P_{\text {sand }}$ is the percentage sand in each grid cell. In a similar manner, the wave speed $c$ for subsurface land flow $\left(c_{s s l}\right)$ also varies spatially as: 


$$
c_{\text {ssl }}= \begin{cases}0.25, & P_{\text {sand }}<30 \\ 0.25\left(70-P_{\text {sand }}\right) / 40, & 30 \leq P_{\text {sand }} \leq 70 \\ 0, & P_{\text {sand }}>70 .\end{cases}
$$

The wave speed used for surface land flow $\left(c_{s l}\right)$, surface river flow $\left(c_{s r}\right)$, and subsurface river flow $\left(c_{s s r}\right)$ are $0.30,0.60$, and 0.25 , respectively. These changes have the combined effect of stopping or reducing subsurface flows in highly sandy soils but maintaining and potentially enhancing return flows from groundwater to surface waters in downstream areas that are less sandy. The spatially varying functions (3) and (4) do not attempt to reproduce local-scale complexities of surface-groundwater behaviour in the Sahelian region (i.e. "Sahelian Paradox"), explored in more detailed modelling studies for the Sahelian aquifer (Massuel et al. 2011) and Sudanian hillslope hydrology (Richard et al. 2013). Instead, Eqs. (3) and (4) aim to broadly emulate the net impact on river flows in a simple but effective way and at scales commensurate with a regional-scale $(10 \mathrm{~km} \times 10 \mathrm{~km}$ resolution) hydrological model.

iii. A population-dependent function has been introduced to accommodate losses from rivers associated with anthropogenic water use. These are based on AQUASTAT estimates of current water use by country in all sectors (quantity of water withdrawn for municipal, industrial, and agricultural purposes) in litres/person/day (FAO 2016). Figure $2 \mathrm{~d}$ shows how these estimates vary by country, with water use per person ranging from 909 1/person/day in Mauritania to 32 1/person/day in Benin. For HMF-WA, an association between gridded population data and water extraction from rivers has been established by linking gridded population numbers in each grid cell with the nearest downstream river grid cell. In the HMF-WA, water demand per person for each country ( $\left.W_{\text {use }}\right)$ abstracted (assumed constant throughout the year and fully consumed) from nearest downstream river grid cell is estimated as follows:

$$
W_{\text {use }}=W_{\text {person }} \times P_{\text {river }}
$$

where $W_{\text {use }}$ is water use (litres/day), $W_{\text {person }}$ is water use per person (litres/person/ day), and $P_{\text {river }}$ is the number of people hydrologically associated with the nearest river. This relationship also allows future scenarios of population growth (Fig. $2 \mathrm{~d}$ inset) for the West African region (UN 2017), to be linked with water use.

The impact of these three model enhancements on the HMF-WA routing model Eq. (1) can be summarised as follows:

$$
\frac{\partial Q}{\partial t}+c \frac{\partial Q}{\partial x}=c\left(u+R_{v}-E_{\text {loss }}-W_{\text {use }}\right)
$$

with the impact of $R_{v}, E_{\text {loss }}$, and $W_{\text {use }}$ varying across the HMF-WA model domain according to spatial datasets of open water, population, and soil texture.

\subsection{Observation-based driving data}

The temporal driving data for HMF-WA are daily precipitation and PE. For the observational-period model assessments, daily precipitation from CHIRPS (Climate Hazards Group Infra-Red Precipitation with station data; Funk et al. 2014) at a $0.05^{\circ} \times 0.05^{\circ}$ (approximately $5 \mathrm{~km} \times 5 \mathrm{~km}$ ) resolution and daily PE from GLEAM (Global Land 
Evaporation Amsterdam Model; Martens et al. 2017) were used to drive the model. GLEAM PE estimates are derived using the Priestley and Taylor equation (Priestley and Taylor 1972) using observations of surface net radiation and near-surface air temperature at a $0.25^{\circ} \times 0.25^{\circ}$ (approximate grid of $25 \mathrm{~km} \times 25 \mathrm{~km}$ ) grid resolution (Martens et al. 2017). Both the rain and PE driving data were re-gridded onto the $0.1^{\circ} \times 0.1^{\circ} \mathrm{HMF}-\mathrm{WA}$ model grid and divided equally down to provide the 4-hourly driving data required by the HMF. For the present-day and future climate simulations, the observed precipitation and PE were directly replaced with climate model data (described in Section 3.3).

Several observation-based rainfall datasets are currently available for sub-Saharan Africa. Le Coz and van de Giesen (2020) recently reviewed and evaluated several rainfall datasets over different parts the region. They recommended the use of CHIRPS for flood and drought studies undertaken in Burkina Faso and Mozambique by Dembélé and Zwart (2016) and Toté et al. (2015), respectively. Dembélé et al. (2020b) also evaluated the suitability of 17 available gridded rainfall datasets for large-scale hydrological modelling in the Volta River basin and showed that CHIRPS is one of the best-performing datasets for streamflow simulation. The study also established that none of the rainfall datasets they tested consistently performed well in reproducing the spatiotemporal rainfall variability. In other words, the best-performing dataset for the temporal dynamics is not necessarily the best for reproducing the spatial variabilities where there is more uncertainty in representation of spatial hydrological processes. Dembélé et al. (2020a) also evaluated twelve satellite and reanalysis evaporation datasets for use within a distributed mesoscale hydrologic model and showed that GLEAM is one of the best-performing datasets. Although there are many weaknesses in observation-based spatiotemporal datasets across West Africa (Peugeot et al. 2011), CHIRPS and GLEAM can be considered a good source of data to drive the HMF-WA regional hydrological model.

Typically, the HMF-WA is not calibrated to individual catchment conditions using observed flow data. Instead, spatial datasets of physical and soil properties are used to configure the model hydrology to local conditions. These spatial datasets consist of slope, flow network (D8), soil properties, land cover (particularly waterbodies such as lakes and wetlands), and population which is linked to water demand. River flow network and catchment area information at a $0.1^{\circ} \times 0.1^{\circ}$ grid were obtained from Wu et al. (2012), which are derived from the HydroSHEDS database (Lehner et al. 2008). Soil parameters-soil texture (percentage of sand, silt, and clay), organic carbon, bulk density, and soil depth to bedrock-are obtained from ISRIC World Soil Information (Ribeiro et al. 2018). Lake shapefiles are obtained from two sources, the HydroLAKES database (Messager et al. 2016), with additional shapefiles acquired by processing satellite images of the Niger River Inland Delta and Lakes District (Fig. 2c). Present-day water use by sector (municipal, industrial, and agricultural) and country was gathered from the AQUASTAT database as shown in Fig. 2d (FAO 2016). Historical population data at an resolution of $\sim 10 \mathrm{~km} \times 10 \mathrm{~km}$ were obtained from the History database of the Global Environment (HYDE) (Klein Goldewijk et al. 2010, 2011), and projected population estimates were obtained from UN (2017) for 2019 to 2100 . Land cover and change in land use were not explicitly included as their impacts were assumed to be negligible in large (continental) scale simulations.

\subsection{Climate model driving data for future scenarios}

To understand the impact of projected climate change on hydrological response at the regional scale, daily bias-corrected climate model data from CMIP5 were used to drive the 
HMF-WA hydrological model. CMIP5 provides simulations from Global Climate Models (GCMs) for the preindustrial period, historical period (1860-2005), and future climate projections (2006-2099) based on Representative Concentration Pathways (RCPs) (Meehl et al. 2009; Taylor et al. 2012). RCPs refer to the concentration pathway extending up to 2100, for which integrated assessment models (IAMs) produced corresponding emission scenarios linking main features of society and economy with the Earth biosphere and atmosphere systems into one modelling framework (van Vuuren et al. 2011).

Here, changes in HMF-WA-simulated river flows were evaluated for 2 RCPs:

- RCP2.6-Radiative forcing peaks at approximately $3 \mathrm{Wm}^{-2}$ before 2100 and then declines.

- RCP8.5-Radiative forcing reaches greater than $8.5 \mathrm{Wm}^{-2}$ by 2100 and continues to rise for some amount of time.

The CMIP5 climate model data used in this study consisted of 4 variables (daily precipitation, near-surface air temperature, and daily maximum and minimum surface air temperature) post-processed to a $0.5^{\circ} \times 0.5^{\circ}$ grid $(\sim 50 \mathrm{~km} \times 50 \mathrm{~km})$ by Famien et al. (2018). Climate models sometimes exhibit systematic biases in variables such as rainfall, arising from simplification of complex atmospheric processes (i.e. physical and thermodynamic processes), as a result of scale and model resolution (e.g. representation of convection) and numerical solution schemes. To overcome this problem, "bias-corrected" climate data are often used in climate impact studies as they can provide more realistic-looking realisations of present-day climate variables. However, there are ongoing concerns that the process of "correcting" climate model data against observations can introduce additional uncertainty (e.g. Maraun et al. (2017)). Here, both bias-corrected and un-corrected or "raw" daily CMIP5 climate model variables from 20 RCP2.6 and 29 RCP8.5 ensemble members from different models have been used to drive the HMF-WA in order to understand how they affect estimation of projected climate impacts on river flows. The bias-corrected data (Famien et al. 2018) were derived using the CDF-t method (Michelangeli et al. 2009) over Africa using EWEMBI, which was produced by ISIMIP as reference dataset (Frieler et al. 2017; Lange 2018). PE is not available directly from the climate models and has been estimated from daily mean, maximum, and minimum surface air temperature using the Hargreaves equation (Hargreaves and Samani 1985). For the duration of the AMMA-2050 study presented here, the full suite of the new generation CMIP6 (Eyring et al. 2016) climate model data was not available, so it could not be included. However, recent work using a limited subset of CMIP6 data (Monerie et al. 2020) showed that CMIP5 pattern in precipitation change over the Sahel is reproduced by CMIP6 simulations with some changes in magnitude.

\subsection{Anthropogenic water use in future periods}

Estimates of anthropogenic water demand for projected future periods (2050s and 2080s) were derived by multiplying present-day water usage for different sectors (Fig. 2d) by projected population growth (UN 2017). Water usage per person was assumed to stay the same in future; future changes in river networks, lakes, and wetlands were assumed to be negligible; and possible future reservoir developments were not considered. In this study, two water demand scenarios, (i) present-day water demand and (ii) water demand linked to projected population growth, were considered. Future socio-economic developments including 
agricultural expansions (related to population growth) are implicitly accounted for through the projected population-linked water demand scenario (Eq. 5).

\subsection{Flood frequency analysis}

In order to understand the impact of projected changes in climate and anthropogenic water use on HMF-WA-simulated peak river flows, a flood frequency change analysis was undertaken for each $10 \mathrm{~km} \times 10 \mathrm{~km}$ river grid cell for present-day and projected future periods. Specifically, for each river grid cell across the West Africa domain, HMF-WA-simulated annual maximum (AM) flows for each calendar year were ordered and their Gringorten plotting positions determined (Gringorten 1963) before fitting a generalised logistic distribution at each point using L-moments (Robson and Reed, 1999). Flood peaks were plotted against their return period (the average interval between peaks exceeding a given magnitude) to provide a flood frequency curve. Strictly, the fitted curve should not be extrapolated much beyond the length of the data period (30 years), though in practice, the need to explore projected climate impacts for more extreme flood events encourages such extrapolation. This approach to evaluating projected future changes in extreme flows implicitly assumes climate stationarity over current and future periods of climate model data, an assumption which is widely made in climate impacts studies (e.g. Kay and Jones (2012)), but is not strictly correct for either climate model, or observed West Africa rainfall (see for example Chagnaud et al. (2021), Wilcox et al. (2018)).

\section{Model performance assessment using observed discharge data}

\subsection{The assessment approach}

Observed daily river discharge data for 20 gauging stations (S1 to S20 in Fig. 2a) were obtained from "The Global Runoff Data Centre (GRDC), 56,068 Koblenz, Germany" (https://www.bafg.de/GRDC/EN/Home/homepage_node.html) and used in the model performance assessment from 1 January 1981 to 31 December 2010.

The statistical performance measures used in this study are the Nash-Sutcliffe Efficiencies $\left(N S E, N S E_{l o g}\right)$ and the relative bias $(B I A S)$ :

i. The Nash-Sutcliffe Efficiency (NSE) index measures the relative magnitude of the model error compared to the observed data (Nash and Sutcliffe 1970):

$$
N S E=1-\frac{\sum_{i=1}^{n}\left(Q_{o, i}-Q_{m, i}\right)^{2}}{\sum_{i=1}^{n}\left(Q_{o, i}-\overline{Q_{o}}\right)^{2}}
$$

where $Q_{o, i}$ is the observed flow for time step $i, Q_{m, i}$ is the modelled flow for time step $i, \overline{Q_{o}}$ is the mean of observed data, and $n$ is the number of time steps. The NSE can range between $-\infty$ and 1 where $N S E=1$ indicates a perfect match between modelled and observed flows, $N S E=0$ indicates that the modelled flows are only as accurate as the mean of the observed flows, and NSE $<0$ indicates that the mean of the observed flows is a better predictor of the flow than the model. The NSE is most suitable for assessing a model's simulation of high flows. 
ii. The $N S E_{l o g}$ is the standard NSE applied to the logarithm of flow data as follows:

$$
N S E_{l o g}=1-\frac{\sum_{i=1}^{n}\left(\ln \left(Q_{o, i}+\varepsilon\right)-\ln \left(Q_{m, i}+\varepsilon\right)\right)^{2}}{\sum_{i=1}^{n}\left(\ln \left(Q_{o, i}+\varepsilon\right)-\ln \left(\overline{Q_{o}+\epsilon}\right)\right)^{2}}
$$

where $\varepsilon$ is a small number usually defined as $\varepsilon=\overline{Q_{o}} / 100$. The $N S E_{l o g}$ values range between $-\infty$ and 1 and can be interpreted in the same way as the NSE. The $N S E_{\log }$ is most useful for assessing model simulation of low to mid-range flows.

iii. The relative Bias $(B I A S)$ indicates the magnitude of modelled flow errors relative to observed flows.

$$
B I A S=\frac{\sum_{i=1}^{n}\left(Q_{o, i}-Q_{m, i}\right)}{\sum_{i=1}^{n} Q_{o, i}}
$$

The BIAS ranges from $-\infty$ to $+\infty$ with a value of 0 indicating no model bias (i.e. no over- or under-estimate), BIAS $>0$ indicates model underestimation, and $B I A S<0$ indicates model overestimation.

\subsection{Results: model assessment against observations}

The simulation was assessed by comparing observed and simulated daily river flows at 20 gauged locations across 10 countries including four major river basins Senegal, Volta, Niger, and Chad for a 30-year period between 1981 and 2010. Figure 3a compares gauged and simulated daily river flows for 20 catchments from 1 May 1981 to 30 April 1986 (i.e. five seasonal cycles of continuous data availability and very little missing data in most of the gauging stations) and shows that the model simulates gauged daily river flows reasonably well in most of the catchments. Figure $3 \mathrm{~b}$ presents the three performance statistics $\left(N S E, N S E_{\text {log }}\right.$, and BIAS) for each gauging station, model performance across West Africa is shown in Fig. 3c, and overall performance is summarised in Table 1. Model performance can be considered satisfactory where $N S E>0.50, N S E_{\text {log }}>0.50$, and $B I A S^{*}<0.45$ (Moriasi et al. 2015). Table 1 shows that the performance measures NSE, NSE $E_{\text {log }}$, and BIAS can be considered satisfactory or better in the majority of the catchments assessed $(14,17$, and 15 catchments out of 20, respectively). Typically, less-satisfactory catchments (NSE, $\left.\mathrm{S} 1, \mathrm{~S} 3, \mathrm{~S} 5, \mathrm{~S} 9, \mathrm{~S} 18, \mathrm{~S} 19 ; N S E_{\text {log }}, \mathrm{S} 9, \mathrm{~S} 15, \mathrm{~S} 18 ; B I A S, \mathrm{~S} 1, \mathrm{~S} 5, \mathrm{~S} 18, \mathrm{~S} 19, \mathrm{~S} 20\right)$ are relatively small and mostly upland regions (e.g. the River Lim in Chad-S5) or flashy (e.g. the River Hadejia, Station Nigeria-S18). In general, there is no apparent relationship between model performance and the magnitude of observed flows among the different stations and climate zones. In steeper upland (e.g. S5) or flashy (e.g. S18) catchments, poorer model performance can most likely be attributed to the use of daily rainfall driving data and possibly also the model representation of the hydrological response of steep upland catchments to effective rainfall.

Figure $3 \mathrm{c}$ shows that across West Africa, the medians of $N S E, N S E_{\text {log }}$, and BIAS are $0.62,0.82$, and $0.06(6 \%)$, respectively, whereas within River Niger catchment, the medians are $0.69,0.85$, and $0.08(8 \%)$. It also shows that for the high river flow season between July and December across West Africa, the medians of NSE, NSE $E_{l o g}$, and BIAS are 0.53, 0.67, and $0.06(6 \%)$. Overall, HMF-WA simulates high river flows well, and low flows extremely 


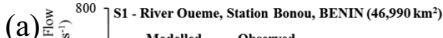

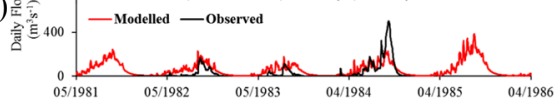

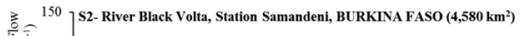

亭命

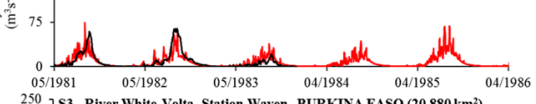

$\left.{ }^{250}\right]$ S3 - River White Volta, Station Wayen, BURKINA FASO $\left(20,880 \mathrm{~km}^{2}\right)$

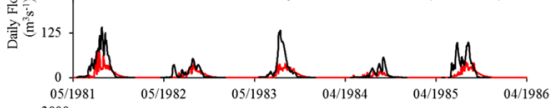

$\left.{ }^{3000}\right]^{\text {S4 - River Sangha, Station Salo, CENTRAL AFRICAN REPUBLIC }}$

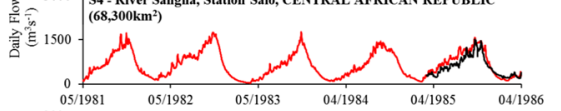

${ }^{800}$ ] S5 - River Lim, Station Oull Bangala, CHAD $\left(4,360 \mathrm{~km}^{2}\right)$

站 400

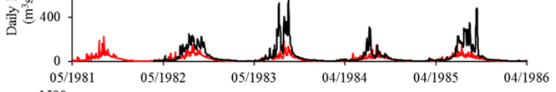

$\Rightarrow 15007 \mathrm{S6}$ - River White Volta, Station Nawuni, GHAVA $\left(92,950 \mathrm{~km}^{2}\right)$

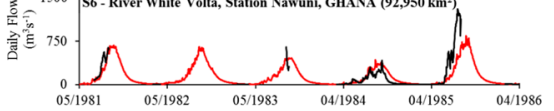

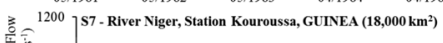
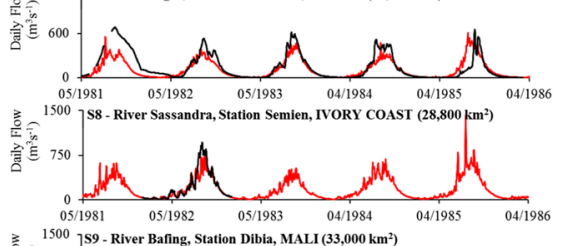

${ }^{1500}$ 'S9 - River Bafing, Station Dibia, MALI $\left(33,000 \mathrm{~km}^{2}\right)$

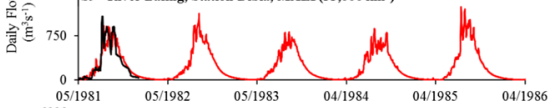

6000 $\mathbf{S 1 0}$ - River Niger, Station Banankoro, MALI $\left(71,750 \mathrm{~km}^{2}\right)$

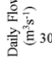

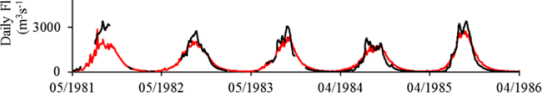

(b)

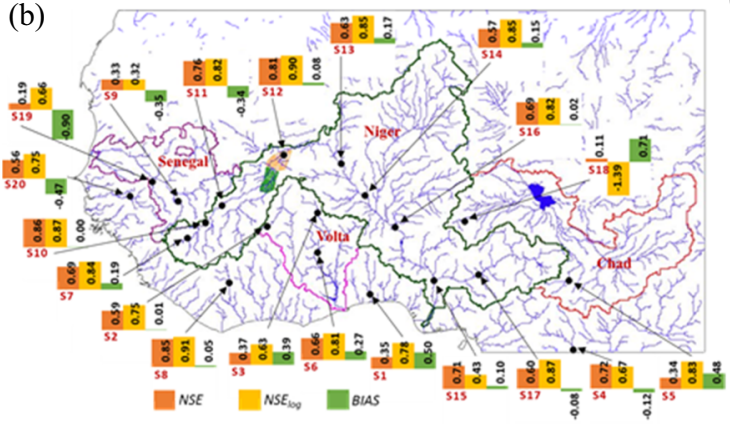

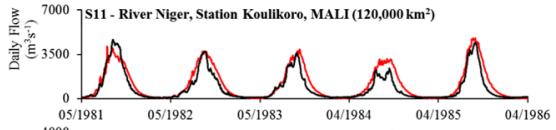

$\left.{ }^{4000}\right]^{\mathbf{S} 12}$ - River Niger, Station Dire, MALI $\left(340,000 \mathrm{~km}^{2}\right)$

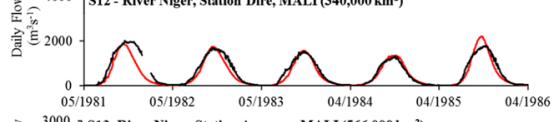

${ }^{3000}$ S13- River Niger, Station Ansongo, MALI $\left(566,000 \mathrm{~km}^{2}\right)$

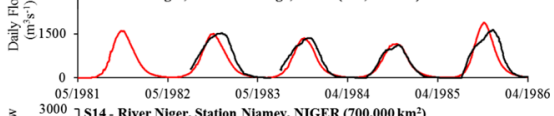

$30007^{\mathrm{S} 14}$ - River Niger, Station Niamey, NIGER $\left(700,000 \mathrm{~km}^{2}\right)$

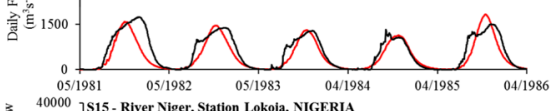

40000 S15 - River Niger, Station Lokoja, NIGERIA

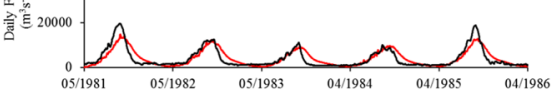

${ }^{4000}$ ] S16 - River Niger, Station Yidere Bode, NIGERIA
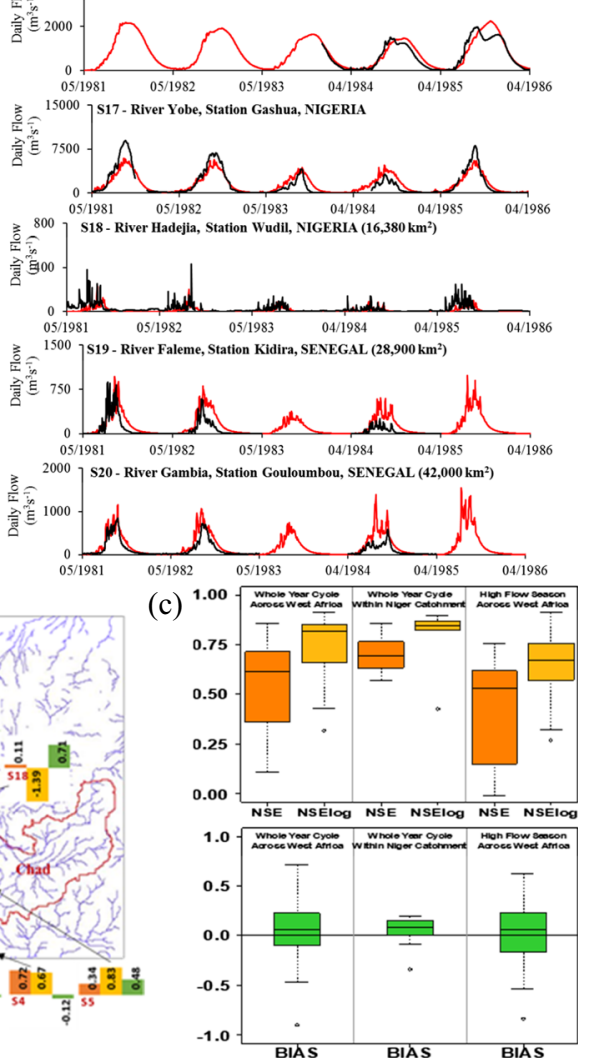

Fig. 3 a Comparison of daily observed and modelled flows for 20 catchments from 1 May 1981 to 30 April 1986, b Nash-Sutcliffe efficiencies $\left(N S E, N S E_{l o g}\right)$ and relative bias (BIAS) for each catchment, c performance statistics summary across West Africa, using the same orange/gold/green colours as (b). 


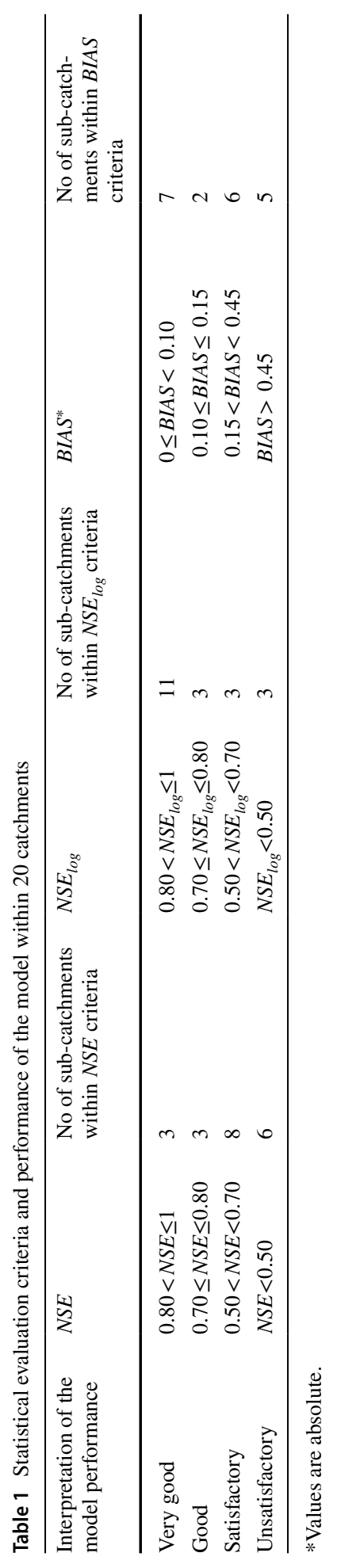


well across West Africa, particularly within the Niger basin, but has a slight tendency to overestimate flows in both regions.

To understand how HMF-WA simulation errors vary across the model domain, Fig. 4 presents frequency and cumulative distributions of model uncertainty (\%) across all catchments and observations. Specifically, for each data point (model-estimated and observed flow for all catchments), the absolute deviation has been calculated and normalised by the $90 \%$ variation (i.e. 95 th percentile minus 5 th percentile) and expressed as a percentage. To exclude outliers, the $90 \%$ variation was used in preference to the absolute range. HMF-WA model uncertainty for more than $90 \%$ of data points is less than $20 \%$ (of the $90 \%$ variation).

The HMF-WA model performance assessment provides confidence that present-day hydrological and anthropogenic influences are reasonably well across West Africa and provides a sound basis for estimating the impact of projected climate and anthropogenic influences on river flows across this region.

\section{Climate change impact assessment}

\subsection{Assessment of the impact of CMIP5 climate projections on river flows}

The climate model-driven hydrological model simulations were undertaken in a very similar way to the observed model runs (Section 4). Datasets of precipitation and PE required by the HMF-WA were provided by CMIP5 ensembles of bias-corrected and un-corrected climate model data. Specifically, the HMF-WA was run for three 30-year periods, using an ensemble of climate model data representing a baseline and two future periods each with two emissions scenarios (RCP2.6 and RCP8.5):

- 1 January 1970 to 31 December 1999 (“baseline”)

- 1 January 2040 to 31 December 2069 (“2050s")

- 1 January 2070 to 31 December 2099 (“2080s”)

To understand the impact of projected future anthropogenic water demand on river flows across West Africa, two water demand scenarios were also evaluated for the future periods: (i) present-day water demand and (ii) water demand scaled by projected population growth in West Africa (Section 3.4). These two water demand scenarios aim to represent

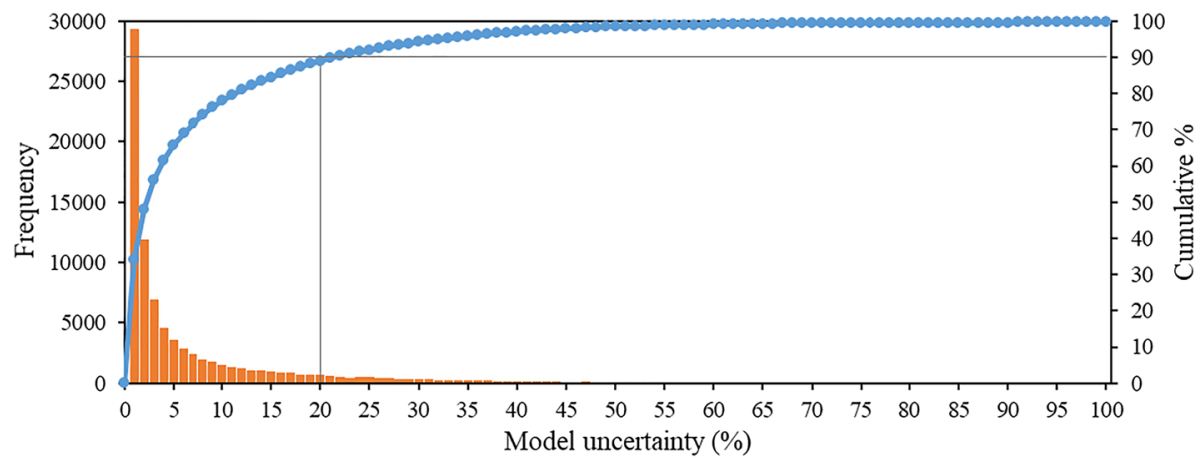

Fig. 4 Frequency and cumulative percentage distributions of model uncertainty 
the envelope of uncertainty in future projections. Although alternative scenarios such as faster population growth have not been considered here, their deviation from scenario (ii) may be limited by future developments in water use efficiency.

To illustrate river flows simulated using the CMIP5 climate model ensemble, mean monthly flows over 30 years are shown in Fig. 5 for the Dire gauging station (Station S12 in Fig. 1a) for the baseline period, 1979 to 1999, using un-corrected (Fig. 5a) and bias-corrected (Fig. 5b) climate model data. Observed mean monthly river flows are indicated with red dots. The influence of bias-correction on HMF-WA-simulated river flows is apparent and has the effect of greatly reducing the variability in river flows from different ensemble members and improving the similarity to observed flows. For the baseline period, the $25^{\text {th }}$, $50^{\text {th }}$, and $75^{\text {th }}$ percentiles of differences between observed and simulated mean October (highest flow month) flows are $-16 \%,-11 \%$, and $-9 \%$, respectively, using bias-corrected data and $-32 \%, 25 \%$, and $56 \%$, respectively, using un-corrected data which clearly shows the impacts of bias and un-corrected data on simulation.

In this study, climate change impacts on river flows have been quantified in terms of the change between baseline and future and were evaluated using both bias-corrected and un-corrected CMIP5 data. A further two sets of hydrographs (Fig. 5c and d) show monthly mean ensemble flows in the 2050s (RCP8.5) from 2040 to 2069. The ensemble of simulated flows for the 2050s shows more variability in magnitude than the baseline period, even when bias-corrected.

\subsection{Assessment of the impact of climate change on seasonal river flows across West Africa}

Across the Sahel, precipitation typically occurs during one rainy season in July, August, and September (JAS) due to the shift of the Intertropical Convergence Zone (ITCZ) to

(a) Mean monthly river flows for the baseline period using un-corrected

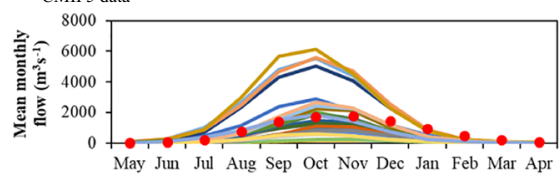

(c) Mean monthly river flows in the 2050s using un-corrected CMIP5 data (RCP8.5)

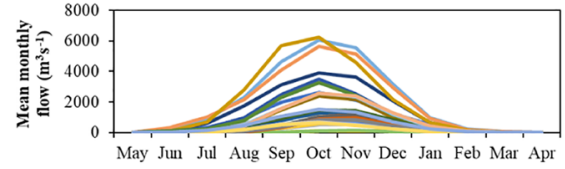

- ACCESS1.0

- CanESM2

—CSIRO-Mk3.6.0

HadGEM2-CC

-IPSL-CM5B-LR CMIP5 data
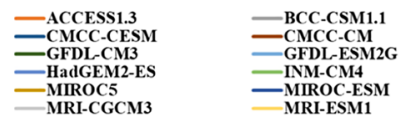

(b) Mean monthly river flows for the baseline period using bias-corrected CMIP5 data

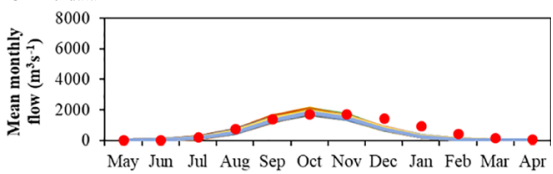

(d) Mean monthly river flows in the 2050s using bias-corrected CMIP5 data (RCP8.5)
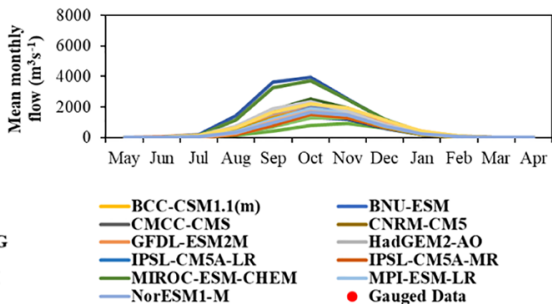

Fig. 5 Comparison of HMF-WA-simulated mean monthly flows at the Dire gauging station, River Niger during the baseline period (1970 to 1999), and a future period RCP8.5 (2050s: 2040 to 2069) using uncorrected and bias-corrected CMIP5 data. a Mean monthly river flows for the baseline period using un-corrected CMIP5 data. b Mean monthly river flows for the baseline period using bias-corrected CMIP5 data. c Mean monthly river flows in the 2050s using un-corrected CMIP5 data (RCP8.5). d Mean monthly river flows in the 2050s using bias-corrected CMIP5 data (RCP8.5) 
the north (Roudier et al. 2014), whereas southern parts of West Africa have two rainy seasons, one from April to mid-July and another from September to October. August precipitation is strongest (Sanogo et al. 2015) and represents approximately $30 \%$ of the yearly total in the West African Sahelian zone. In southern areas (Sudano-Guinean zone and Guinea coast), rainfall peaks typically occur in June and October during the main and minor rainy season ( $\mathrm{Ta}$ et al. 2016). The annual precipitation range is between 400 and $600 \mathrm{~mm}$ for the Sahelian zone, 900 and $1200 \mathrm{~mm}$ for the Sudano-Guinean zone, and 1500 and $2000 \mathrm{~mm}$ for the Guinea coast (Ta et al. 2016). Fig. 6a shows the multi-model median projected future change in JAS precipitation ( $\mathrm{mm} / \mathrm{month})$ across West Africa between the baseline period and the 2050s and 2080s, for RCP2.6 and RCP8.5. In the Sahelian region, the projected future change in precipitation is more pronounced than in other parts of West Africa, with projected increases in the central and eastern region while the western part become drier. As expected, these relative changes are accentuated in the RCP8.5 scenario compared to RCP2.6. Biasutti (2019) observed that seasonal precipitation characteristics have altered in recent decades, with rainfall becoming more
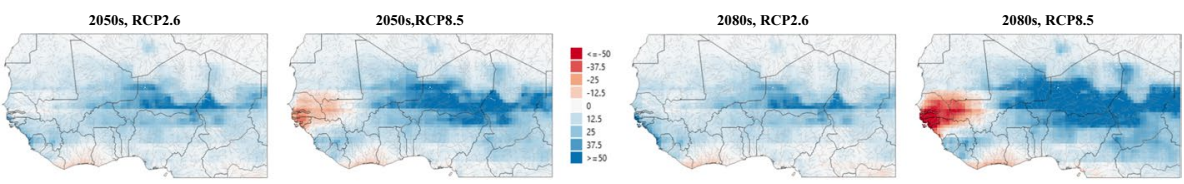

(a) Median change in JAS precipitation from baseline to future $(\mathrm{mm} / \mathrm{month})$
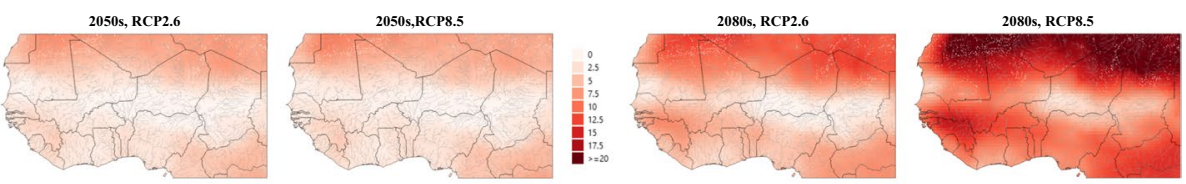

(b) Median change in JAS PE from baseline to future $(\mathrm{mm} / \mathrm{month})$
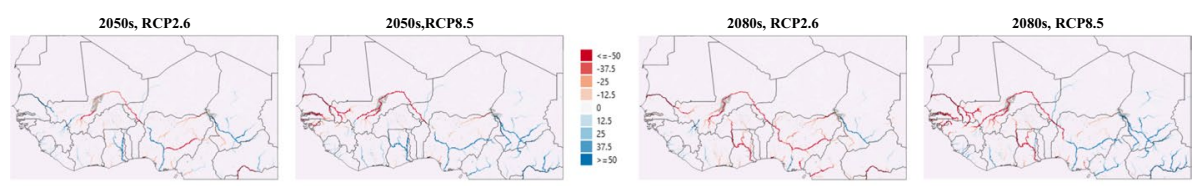

(c) Median change in monthly ASON river flow from baseline to future $\left(\mathrm{m}^{3} / \mathrm{s}\right)$
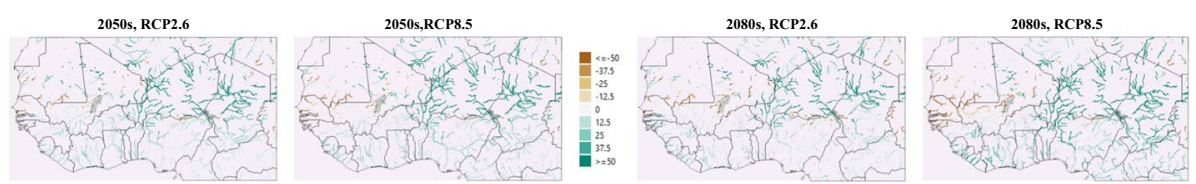

(d) Median percentage change in peak river flows from baseline to future (30- year return period, bias-corrected climate data)
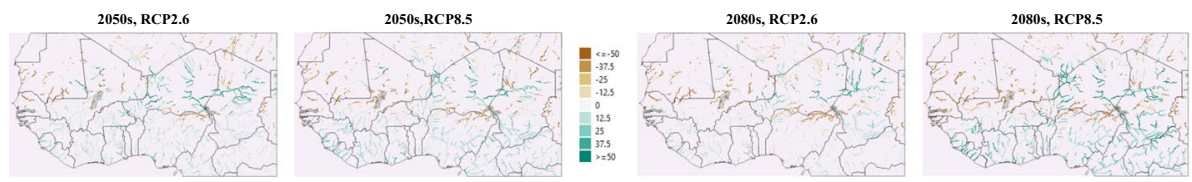

(e) Median percentage change in peak river flows from baseline to future (30-year return period, un-corrected climate data)

Fig. 6 Maps of multi-model median values of a change in JAS monthly precipitation from baseline to future $(\mathrm{mm} / \mathrm{month})$, b change in in JAS monthly precipitation $(\mathrm{mm} / \mathrm{month})$, c change in monthly ASON river flow from baseline to future $\left(\mathrm{m}^{3} \mathrm{~s}^{-1}\right)$, and $\mathbf{d}$, e median percentage change in peak river flows from baseline to future (30-year return period) and bias-corrected or un-corrected climate data respectively. All plots are for population based increases in future water use scenario 
intense and intermittent away from the west coast. Biasutti (2019) indicates that the Sahel precipitation seasonal accumulations arise from large-scale processes connected to the Hadley cell and the regional monsoon circulation, which are largely resolved by the current generation of GCMs. This provides some assurance in the CMIP5 future projections used here; however, uncertainties in systematic biases, divergence across model future projections, and poor representation of high-resolution atmospheric processes in GCMs remain.

The multi-model median projected future change in JAS PE $(\mathrm{mm} / \mathrm{month})$ is presented in Fig. 6b, which indicates that PE is expected to be higher in RCP 8.5 than RCP 2.6. The patterns largely coincide with projected future precipitation changes in the Sahel, so those regions that are generally expected to be wetter are also associated with lower PE.

In order to assess the impact of projected climate change on river flows during the high flow season across West Africa (August to November-ASON) resulting from the rainy season in JAS, changes in river flows were estimated for each GCM ensemble member. Fig. $6 \mathrm{c}$ presents maps of the ensemble median change in river flows $\left(\mathrm{m}^{3} \mathrm{~s}^{-1}\right)$ across West Africa, which highlight the large spatial variation in projected future changes, both increases and decreases. Projected decreases in mean flows are particularly apparent in the upper reaches of the River Niger in Mali and Niger for all RCPs and future time horizons and in the Senegal River in the 2050s for RCP8.5 and 2080s for RCP2.6 and RCP8.5. Here, projected changes in mean flows arise from the combined projected future impacts of climate change and anthropogenic water use, the latter having a significant impact on projected future runoff across the region.

To illustrate the spatial variation in the projected impacts on river flows, the median percentage change in flood frequency (30-year return period) is presented in Fig. 6d. The 30-year return period represents more extreme, less frequently observed peak river flows. The maps of median percentage change show significant variation for different parts of West Africa. Across the Sahel, the peak flows are often decreasing in the western region and increasing in the central and eastern regions, in line with projected precipitation changes (Fig. 6a). As expected, the projected changes in peak river flows are more extreme for RCP8.5 and the far-future (2080s).

Figure 6e also shows the median percentage change in peak river flows, but here, uncorrected CMIP5 data have been used. The maps of percentage change in peak flows using both bias- and un-corrected simulations (Fig. 6d and e) show a broadly similar trend in the southern parts of West Africa where in Cote d'Ivoire, median percentage changes in peak flows for 30-year return period in the 2050s (RCP 8.5) are $14 \%$ and $17 \%$ for bias-corrected and un-corrected, respectively, and in the 2080 s, they are $28 \%$ and $25 \%$, respectively.

However, in the Sahel, there are some notable differences. In the western Sahel, both sets of results (i.e. with and without bias-correction) indicate that peak flows are likely to decrease in future. However, in eastern areas, results differ and median projected peak flows decrease when un-corrected CMIP5 data are used but increase for bias-corrected data. In the north of Sahel, where total annual rainfall is less than $100 \mathrm{~mm}$ (CILSS, 2016), a projected future change in the balance between annual rainfall and evaporation could result in some simulations with near zero or zero runoff, potentially leading to a nonlinear (abrupt) percentage change in median peak flows. In this region, the low rainfall and limited availability of observations could also be possible sources of uncertainty in bias-correction. It is also worth mentioning that the CMIP5 $0.5^{\circ}$-resolution RCMs used here are too coarse to adequately represent features such as localised rainfall intensification. An understanding of the impact of such changes in rainfall extremes on river flows will require data from the next generation convection-permitting climate models (e.g. Berthou et al. (2019)). 


\subsection{In-country climate change assessment: Senegal, Burkina Faso, and Chad}

The previous sections highlighted the variation in median projected climate change across West Africa from east (wetter, higher flows) to west (drier, lower flows). This section focusses on three countries located within the Sahel, Senegal, Burkina Faso, and Chad (Fig. 2d), for a more in-depth analysis of the drivers of these changes. For this assessment, the bias-corrected CMIP5 data were used as input to the HMF-WA, but the sensitivity of projected changes in peak flows in eastern Sahel to use of bias- or un-corrected climate data (Section 5.2) remains. For each country, Fig. 7a to c illustrate the monthly mean ensemble variation $\left(25^{\text {th }}, 50^{\text {th }}\right.$, and $75^{\text {th }}$ percentiles of seasonal change) of (a) precipitation, (b) PE, and (c) river flow for RCP2.6 (blue shading) and RCP8.5 (red/orange) scenarios in the 2050s and 2080s. The figures indicate that differences in the projected future changes in rainfall (rather than PE) are most likely to be the cause of the different hydrological responses to climate change in each country. While future increases in PE estimates are expected in most ensemble members, the increases are broadly similar for all three countries. Generally, the RCP8.5 scenario has a more pronounced influence on the river flows than RCP2.6 particularly in Senegal (Western Sahel) and Chad (Eastern Sahel), where flows are reduced/increased, respectively. For example, for RCP8.5 in the 2080s, a $54 \mathrm{~mm} /$ month decrease in August rainfall leads to a $207 \mathrm{~m}^{3} \mathrm{~s}^{-1}$ decrease in river flows in September in Senegal, whereas in Chad, a $44 \mathrm{~mm} /$ month increase in August rainfall leads to a $108 \mathrm{~m}^{3} \mathrm{~s}^{-1}$ increase in river flows in October. The overall impact of projected changes in rainfall and PE on flows in Burkina Faso is less pronounced.

The region most likely to incur to an increase in drought vulnerability and water shortages is Western Sahel, particularly Senegal and Mali, which are projected to experience significant reductions in future mean river flows (Figs. 6c and 7c). Conversely, projected future increases in mean river and peak flows in Eastern Sahel would potentially lead to increased flood hazard for countries such as Chad and Niger (Figs. 6d and $7 \mathrm{c})$.

The projected future changes in river flows in each country (Fig. 7c) reflect the combined impacts of the CMIP5-projected precipitation, and PE, however, in-country water demand, which is assumed proportional to population, is also an important factor. In order to understand the influence that projected future water demand has on projected changes in river flows, the future hydrological simulations were repeated assuming future water demand is the same as for the present-day. Figure $7 \mathrm{~d}$ presents "box-and-whisker" plots (which show upper and lower range, upper and lower quartile range, median) of the percentage change in 2- and 30-year return period peak river flows assuming present-day and projected future water demand. Overall, the assumption of higher water use associated with a future population growth scenario results in a modest reduction in peak river flows compared to when present-day water demand is assumed for future periods. Of the three Sahelian countries, the combined impact of rising water use and climate change is greatest in Senegal, where ensemble median peak flows in the 2080s (RCP 8.5) are expected to decrease by $23 \%$ (2-year return period) and $21 \%$ (30-year return period) as a result of a projected $230 \%$ increase in future water use. In contrast, median 30-year return period flows in the 2050s (RCP 8.5 ) are projected to decrease by $28 \%$ in Senegal and increase by $80 \%$ in Chad. This is due the decrease and increase in future precipitation, respectively, with more than double the amount of water usage (person/day) in Senegal compared to Chad (Fig. 2d). 

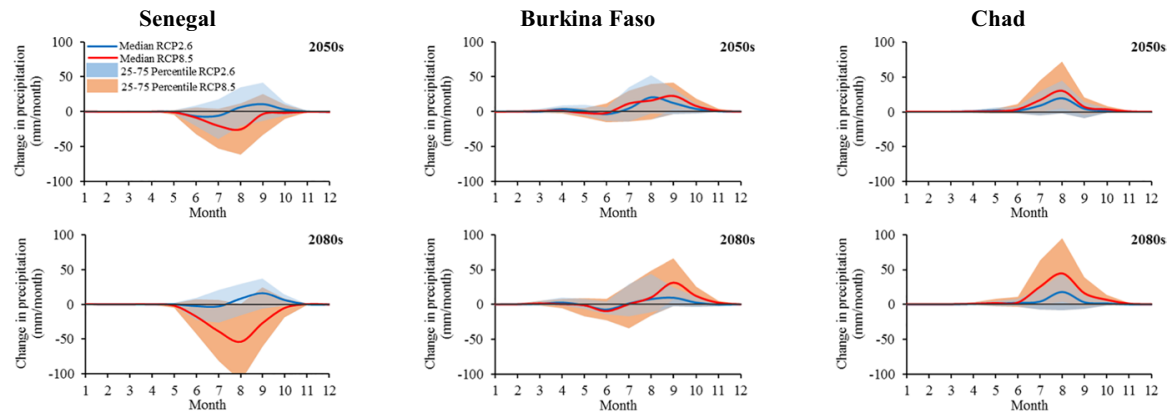

(a) Monthly mean change in precipitation for RCP2.6 and 8.5 for the 2050s and 2080s Senegal

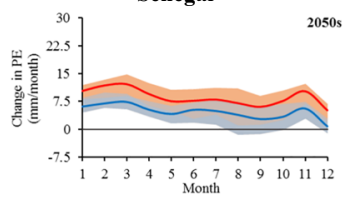

Burkina Faso

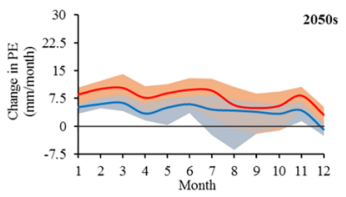

Chad
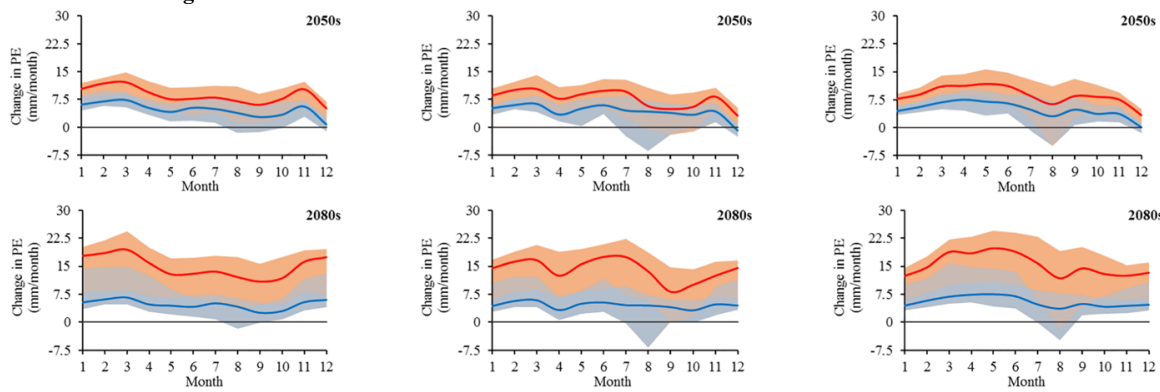

(b) Monthly mean change in PE for RCP2.6 and 8.5 for the 2050s and 2080s

Senegal
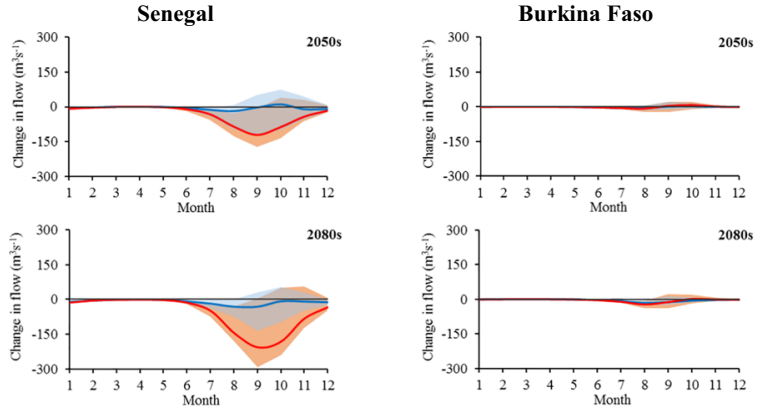

2080 s
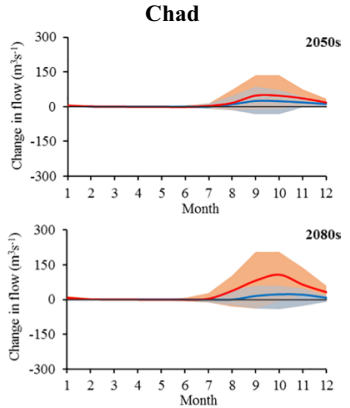

Senegal

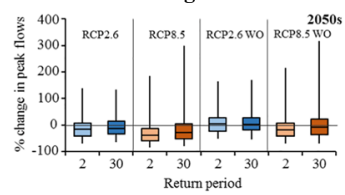

Burkina Faso
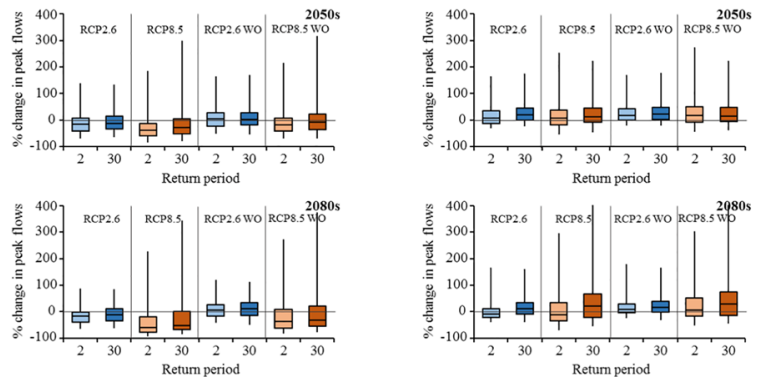

50 s

$080 \mathrm{~s}$

(d) Percentage change in peak river flows at 2- and 30-year return periods for RCP2.6 and 8.5 for the 2050s and 2080s

Fig. 7 Monthly mean change for 3 countries (Senegal, Burkina Faso, and Chad): a precipitation, b PE, c river flow, and d "box-and-whisker" plots of percentage change in peak river flows at 2- and 30-year return periods for RCP2.6 and 8.5 for the 2050s and 2080s, with and without (WO) population based increases in future water use 


\section{Discussion}

The IPCC's Fifth Assessment Report states that rising air temperatures and frequency of some extreme weather events (floods and droughts) are already affecting environments and ecosystems which in turn have direct impact on food and water security, livelihoods, and social economics. However, the future climate impact on river flows across West Africa is less well understood. In this study, the impact of CMIP5-projected climate change on river flows across West Africa is assessed using the grid-based hydrological model HMF-WA which has been enhanced to take account of anthropogenic water use, wetland inundation, and endorheic regions. It is important to acknowledge the range of uncertainties associated with hydrological modelling (Beven 1993), and here, these uncertainties include the discretisation of the model equations, simplified representation of complex hydrological processes (water use, wetland inundation, and endorheic regions), and underlying driving and gauged flow data quality and its processing. Despite all these uncertainties, Section 4 shows that the median relative Bias $(B I A S)$ in simulated flows compared to observed is approximately 6\% across West Africa and 8\% within the River Niger catchment. Overall, the HMF-WA was found to simulate high river flows well and low flows extremely well across West Africa (Section 4).

The HMF-WA simulations undertaken here showed that, as expected, use of bias-corrected (as opposed to un-corrected) CMIP5 data increased agreement between present-day simulated and observed river flows and also decreased the interquartile range in magnitude from $-58 \%$ and $40 \%$ to $-14 \%$ and $31 \%$ for the highest flow month October (Section 5.1). However, the analysis of (percentage) change in river flows between baseline and future periods was relatively unaffected by bias-correction (Section 5.2), but use of bias-corrected data did affect the median percentage change in parts of the Sahel with very low rainfall. Although bias-correction of climate model data has become standard practice (Gohar et al. 2017; Maraun 2016), particularly in agriculture-related modelling (Ramirez-Villegas et al. 2013; Sultan and Gaetani 2016), Ehret et al. (2012) argue that the procedure narrows the uncertainty range in the modelled data without providing an acceptable physical rationalisation and hides rather than reduces uncertainty by modifying spatiotemporal field consistency of each variable independently without considering conservation principles.

The main purpose of the bias-correction is to remove biases in simulated climate variables in both control and scenario GCM runs; however, the bias-correction process generally makes the assumption that the behaviour of the bias is stationary (i.e. biases do not change in the future). Until there is significant improvement in the representation of complex atmospheric processes within GCM with appropriate scale and increased model resolution, bias-corrected climate model data will continue to be used in climate impact studies. The ability to generate realistic climate and river flows for recent historical periods using bias-corrected climate data is particularly useful when communicating the impacts of projected climate change on hydrology and also when collaborating with other science disciplines (e.g. agriculture).

The hydrological model HMF-WA uniquely provides continuous, spatially distributed hydrological simulations for West Africa, from which river flows can be extracted at a range of scales (from sub-catchment scale to regional scale). The projected future changes in flows presented here using CMIP5 climate model driving data (RCP 2.6 and 8.5) across West Africa are broadly in line with other analyses conducted in the region. For example, a study of projected future changes to river flows in the Upper Niger and the Inner Niger Delta using a semi-distributed hydrological model with CMIP5 RCP4.5 data (Thompson 
et al. 2017) also indicated declining seasonal peak flows during the 2050s and 2080s. Similarly, Bodian et al. (2018) analysed the impacts of projected climate change on the Senegal and Gambia river basins using 6 models from CMIP5 (RCP4.5 and RCP8.5) with the GR4J model. Their projections indicated that river flows in the Senegal and Gambia basins would decrease by the $2050 \mathrm{~s}$, in line with results presented here under the RCP8.5 scenario (see Fig. 6c). However, Aich et al. (2014) who analysed projected climate changes to river flows with the SWIM model in four large African basins including the Niger using 19 CMIP5 models (RCP2.6 and RCP8.5) found that the direction of the future trend was not clear (though the majority of model runs indicated increasing flows in the Niger). Here, the HMF-WA hydrological model was able to identify specific areas within the Niger Basin most likely to experience decreased flows (in the upper reaches and headwaters) and increased flows (downstream nearer the coast) and as shown in Fig. 6c. This enhanced spatial understanding highlights the benefits of using a spatially distributed hydrological model such as the HMF-WA for climate impact analyses.

Regional-scale hydrological modelling studies driven by observational datasets or climate model data are subject to multiple levels of uncertainties, from the spatiotemporal climate driving datasets and datasets of landscape properties such as soils to the representation of complex rainfall and hydrological processes at a necessarily coarse resolution. This research has introduced coarse-scale representations of anthropogenic water use, wetlands, and endorheic basins, which, though providing an indication of their impact on river flows at a regional scale, are unlikely to do justice to the complexity of these processes at a local scale. However, at the scale for which this research intended-19 countries spanning West Africa-the results presented here provide a unique and spatially consistent overview of how projected climate change might impact on river flows and water resources across the whole region over the next 80 years. Areas of West Africa have been identified where model-estimated future changes in river flows are of most concern, and it is to be expected that further local-scale hydrological impact assessments will help to reduce some of the uncertainties in the models, their representations of extreme river flows, and their underlying datasets.

\section{Conclusions}

A spatially distributed hydrological model (hydrological modelling framework- - HMFWA") has been developed for West Africa to provide grid-based and spatially consistent simulations of daily river flows at a $0.1^{\circ} \times 0.1^{\circ}$ (approximately $10 \mathrm{~km} \times 10 \mathrm{~km}$ ) spatial grid resolution across the region. The new model takes account of anthropogenic water use and other hydrological influences such as endorheic rivers and wetlands. The performance of the model has been assessed using observed daily river flows at monitoring stations across the region, prior to its use to explore the impact of climate change on river flows across West Africa. An ensemble of CMIP5 regional projections for future scenarios RCP2.6 and RCP8.5 (Famien et al. 2018) has been used to estimate the impact on the monthly mean flows and peak flows across West Africa in the 2050s and 2080s.

Across the Sahel, the analysis presented here indicates that projected future climates will exert considerable influence on river flows, particularly extreme river flows. Specifically, hydrological impact projections indicate that western parts of the Sahel can expect significant decreases in peak river flows (median change of $-28 \%$ in Senegal), 
while eastern Sahel can expect significant increases (median change of $+80 \%$ in Chad) by the 2050s. Generally, there is some agreement between the different climate model projections (Todzo et al. 2020), and the research presented here also indicates some consistency in the future direction of change in river flows. Outside the Sahel, projected peak flows mostly increase in areas where precipitation also increases, but the hydrological response of the landscape to projected changes in rainfall is highly nonlinear. Model simulations presented here also indicate that projected future water demand has only a modest influence on changes in peak river flows across the region compared to projected future impacts of climate change. Overall, the projected future changes in mean and peak river flows are highly spatially variable across West Africa particularly in the Sahelian region, which appears to be particularly vulnerable to the severity of projected climate change. Although climate impacts are discussed here at a regional scale (e.g. western or eastern Sahel), climate change impacts on flows would be expected to vary between individual catchments and river systems. An advantage of the spatially distributed hydrological model used here (HMF-WA) is the ability to provide climate impact assessments for rivers on a $0.1^{\circ} \times 0.1^{\circ}$ (approximately $10 \mathrm{~km} \times 10 \mathrm{~km}$ ) grid across West Africa. To support stakeholders and decision-makers across the region, these more-granular data are now being made publicly available (Rameshwaran et al. 2021), together with a summary of the current model limitations and uncertainties.

Across Eastern Sahel, most of the hydrological simulations driven by CMIP5 climate data agree that mean and peak flows will increase in future decades, potentially leading to an increased flood hazard (e.g. in Chad and Niger), while in the Western Sahel (e.g. Senegal and Mali), a majority of model simulations agree on projected future decreases in mean and peak flows, and these countries are more likely to experience increased drought vulnerability and water shortages in future.

The changes in projected mean and peak flows river flows could have serious impacts on human life, including immense damage to property, infrastructure and the environment, destruction or loss of agriculture and wildlife, deterioration of health conditions, and lack of progress in socio-economic developments across the region. Therefore, there is an urgent need for the development of an effective mitigation and climate adaptation plan at both regional and national scales. The use here of a distributed hydrological model formulation has enabled the provision of spatially consistent maps and estimates of the hydrological impact of projected climate change across West Africa, for rivers, catchments, regions, and individual countries. Ongoing work aims to provide these data within a GeoPortal, to support stakeholders and policy-makers in the region (e.g. ANACIM-Agence Nationale de l'Aviation Civile et de la Météorologie, Senegal) to develop adaptation pathways and plan for future change across the region. Unless planned and managed well, the impacts of projected climate change on the frequency and magnitude of floods and droughts across West Africa, alongside increasing population, could adversely affect lives, livelihoods, and the environment in the coming decades.

Abbreviations AMMA-2050: African Monsoon Multidisciplinary Analysis-2050; AQUASTAT: FAO's Global Information System on Water and Agriculture; CMIP5 or CMIP6: Coupled Model Inter-comparison Project Phase 5 or 6; EartH2Observe: Global Earth Observation for Integrated Water Resource Assessment; ERA: ECMWF reanalysis; ECMWF: European Centre for Medium-Range Weather Forecasts; EWEMBI: EartH2Observe, WFDEI, and ERA-Interim data Merged and Bias-corrected for ISIMIP; HMF: Hydrological modelling framework; IAM: Integrated assessment models; ISIMIP: The Inter-Sectoral Impact Model Inter-comparison Project; KW: Kinematic wave; PE: Potential evaporation; 
RCP: Representative concentration pathway; UN: United Nations; WA: West Africa; WATCH: Water and Global Change Project; WFDEI: WATCH Forcing Data Methodology Applied to ERA-Interim Data

Funding This research work was supported by the United Kingdom's Natural Environment Research Council (NERC)/Department for International Development (DFID) Future Climate for Africa (FCFA) programme under the African Monsoon Multidisciplinary Analysis-2050 (AMMA-2050) project (NE/ M020428/1).

Data availability Rameshwaran, P.; Bell, V.A.; Davies, H.N.; Kay, A.L. (2021). Historical (1950-2005) and projected (2006-2099) hydrological model (HMF-WA) estimates of monthly mean and annual maximum river flows across West Africa driven by CMIP5-projected climate data. NERC EDS Environmental Information Data Centre. https://doi.org/10.5285/6429828f-6a06-4d2d-8f50-4910b18f7ff4

Code availability Research code was used to simulate the flows.

\section{Declarations}

Conflict of interest The authors declare no competing interests.

Open Access This article is licensed under a Creative Commons Attribution 4.0 International License, which permits use, sharing, adaptation, distribution and reproduction in any medium or format, as long as you give appropriate credit to the original author(s) and the source, provide a link to the Creative Commons licence, and indicate if changes were made. The images or other third party material in this article are included in the article's Creative Commons licence, unless indicated otherwise in a credit line to the material. If material is not included in the article's Creative Commons licence and your intended use is not permitted by statutory regulation or exceeds the permitted use, you will need to obtain permission directly from the copyright holder. To view a copy of this licence, visit http://creativecommons.org/licenses/by/4.0/.

\section{References}

Aich V, Liersch S, Vetter T, Huang S, Tecklenburg J, Hoffmann P, Koch H, Fournet S, Krysanova V, Müller EN, Hattermann FF (2014) Comparing impacts of climate change on streamflow in four large African river basins. Hydrol Earth Syst Sci 18:1305-1321

Albergel J (1987) Sécheresse, désertification et ressources en eau de surface : application aux petits bassins du Burkina Faso. The Influence of Climate Change and Climatic Variability on the Hydrologic Regime and Water Resources. IAHS Publication No 168, Wallingford, pp. 355365

Amani A, Nguetora M (2002) Evidence d'une modification du régime hydrologique du fleuve Niger à Niamey. FRIEND 2002 Regional Hydrology: Bridging the Gap between Research and Practice, Proceedings of the Friend Conference, Cape Town, South Africa, 18-22 March, 2002; Van Lannen, H., Demuth, S., Eds, IAHS publication No 274, Wallingford, UK:449-456

Amogu O, Descroix L, Yéro KS, Le Breton E, Mamadou I, Ali A, Vischel T, Bader J-C, Moussa IB, Gautier E, Boubkraoui S, Belleudy P (2010) Increasing River Flows in the Sahel? Water 2:170-199

Amogu O, Esteves M, Vandervaere JP, Malam Abdou M, Panthou G, Rajot JL, Souley Yéro K, Boubkraoui S, Lapetite JM, Dessay N, Zin I, Bachir A, Bouzou Moussa I, Faran Maïga O, Gautier E, Mamadou I, Descroix L (2015) Runoff evolution due to land-use change in a small Sahelian catchment. Hydrol Sci J 60:78-95

Andersen J, Refsgaard JC, Jensen KH (2001) Distributed hydrological modelling of the Senegal River Basin - model construction and validation. J Hydrol 247:200-214

Bell VA, Kay AL, Jones RG, Moore RJ (2007) Development of a high resolution grid-based river flow model for use with regional climate model output. Hydrol Earth Syst Sci 11:532-549

Berthou S, Kendon EJ, Rowell DP, Roberts MJ, Tucker S, Stratton RA (2019) Larger future intensification of rainfall in the West African Sahel in a convection-permitting model. Geophys Res Lett 46:13299-13307

Beven K (1993) Prophecy, reality and uncertainty in distributed hydrological modelling. Adv Water Resour $16: 41-51$ 
Biasutti M (2019) Rainfall trends in the African Sahel: characteristics, processes, and causes. WIREs Clim Change 10:e591

Bichet A, Diedhiou A (2018) Less frequent and more intense rainfall along the coast of the Gulf of Guinea in West and Central Africa (1981-2014). Climate Res 76:191-201

Blanchet J, Aly C, Vischel T, Panthou G, Sané Y, Diop Kane M (2018) Trend in the co-occurrence of extreme daily Rainfall in West Africa Since 1950. J Geophys Res: Atmos 123:1536-1551

Bodian A, Dezetter A, Diop L, Deme A, Djaman K, Diop A (2018) Future climate change impacts on streamflows of two main West Africa river basins: Senegal and Gambia. Hydrology 5:21

Boko BA, Konaté M, Yalo N, Berg SJ, Erler AR, Bazié P, Hwang H-T, Seidou O, Niandou AS, Schimmel K, Sudicky EA (2020) High-resolution, integrated hydrological modeling of climate change impacts on a semi-arid urban watershed in Niamey. Niger Water 12:364

Boone A, de Rosnay P, Balsamo G, Beljaars A, Chopin F, Decharme B, Delire C, Ducharne A, Gascoin S, Grippa M, Guichard F, Gusev Y, Harris P, Jarlan L, Kergoat L, Mougin E, Nasonova O, Norgaard A, Orgeval T, Ottlé C, Poccard-Leclercq I, Polcher J, Sandholt I, Saux-Picart S, Taylor C, Xue Y (2009) The AMMA Land Surface Model Intercomparison Project (ALMIP). Bull Am Meteor Soc 90:1865-1880

Chagnaud G, Panthou G, Vischel T, Blanchet J, Lebel T (2021) A unified statistical framework for detecting trends in multi-timescale precipitation extremes: application to non-stationary intensity-durationfrequency curves. Theoret Appl Climatol 145:839-860

CILSS (2016) Landscapes of West Africa - A Window on a Changing World. U.S. Geological Survey EROS, 47914 252nd St, Garretson, SD 57030, United States

Crooks S, Kay A, Davies H, Bell V (2014) From Catchment to National Scale Rainfall-Runoff Modelling: Demonstration of a Hydrological Modelling Framework. Hydrology 1:63-88

Dembélé M, Ceperley N, Zwart SJ, Salvadore E, Mariethoz G, Schaefli B (2020) Potential of satellite and reanalysis evaporation datasets for hydrological modelling under various model calibration strategies. Adv Water Resour 143:103667

Dembélé M, Schaefli B, van de Giesen N, Mariéthoz G (2020b) Suitability of 17 gridded rainfall and temperature datasets for large-scale hydrological modelling in West Africa. Hydrol Earth Syst Sci 24:5379-5406

Dembélé M, Zwart SJ (2016) Evaluation and comparison of satellite-based rainfall products in Burkina Faso, West Africa. Int J Remote Sens 37:3995-4014

Descroix L, Mahé G, Lebel T, Favreau G, Galle S, Gautier E, Olivry JC, Albergel J, Amogu O, Cappelaere B, Dessouassi R, Diedhiou A, Le Breton E, Mamadou I, Sighomnou D (2009) Spatio-temporal variability of hydrological regimes around the boundaries between Sahelian and Sudanian areas of West Africa: a synthesis. J Hydrol 375:90-102

Descroix L, Moussa IB, Genthon P, Sighomnou D, Mahé G, Mamadou I, Vandervaere JP, Gautier E, Maiga OF, Rajot J-L, Abdou MM, Dessay N, Ingatan A, Noma I, Yéro KS, Karambiri H, Fensholt R, Albergel J, Olivry J-C (2013) Impact of drought and land - use changes on surface - water quality and quantity : the sahelian paradox. In: Bradley PM (ed) Current perspectives in contaminant hydrology and water resources sustainability. Intech, Rijeka, pp 243-271

Dezetter A, Girard S, Paturel JE, Mahé G, Ardoin-Bardin S, Servat E (2008) Simulation of runoff in West Africa: is there a single data-model combination that produces the best simulation results? J Hydrol 354:203-212

Diedhiou A, Bichet A, Wartenburger R, Seneviratne SI, Rowell DP, Sylla MB, Diallo I, Todzo S, Touré NdE, Camara M, Ngatchah BN, Kane NA, Tall L, Affholder F (2018) Changes in climate extremes over West and Central Africa at $1.5^{\circ} \mathrm{C}$ and $2{ }^{\circ} \mathrm{C}$ global warming. Environ Res Lett 13:065020

Dosio A, Panitz H-J (2016) Climate change projections for CORDEX-Africa with COSMO-CLM regional climate model and differences with the driving global climate models. Clim Dyn 46:1599-1625

Ehret U, Zehe E, Wulfmeyer V, Warrach-Sagi K, Liebert J (2012) HESS Opinions "Should we apply bias correction to global and regional climate model data?" Hydrol Earth Syst Sci 16:3391-3404

Eyring V, Bony S, Meehl GA, Senior CA, Stevens B, Stouffer RJ, Taylor KE (2016) Overview of the coupled model intercomparison project phase 6 (CMIP6) experimental design and organization. Geosci Model Dev 9:1937-1958

Famien AM, Janicot S, Ochou AD, Vrac M, Defrance D, Sultan B, Noël T (2018) A bias-corrected CMIP5 dataset for Africa using the CDF-t method - a contribution to agricultural impact studies. Earth System Dynamics 9:313-338

FAO (2016) AQUASTAT Main Database, Food and Agriculture Organization of the United Nations (FAO)

Frieler K, Lange S, Piontek F, Reyer CPO, Schewe J, Warszawski L, Zhao F, Chini L, Denvil S, Emanuel K, Geiger T, Halladay K, Hurtt G, Mengel M, Murakami D, Ostberg S, Popp A, Riva R, Stevanovic M, Suzuki T, Volkholz J, Burke E, Ciais P, Ebi K, Eddy TD, Elliott J, Galbraith E, Gosling 
SN, Hattermann F, Hickler T, Hinkel J, Hof C, Huber V, Jägermeyr J, Krysanova V, Marcé R, Müller Schmied H, Mouratiadou I, Pierson D, Tittensor DP, Vautard R, van Vliet M, Biber MF, Betts RA, Bodirsky BL, Deryng D, Frolking S, Jones CD, Lotze HK, Lotze-Campen H, Sahajpal R, Thonicke $\mathrm{K}$, Tian H, Yamagata Y (2017) Assessing the impacts of $1.5^{\circ} \mathrm{C}$ global warming - simulation protocol of the Inter-Sectoral Impact Model Intercomparison Project (ISIMIP2b). Geosci Model Dev 10:4321-4345

Funk CC, Peterson PJ, Landsfeld MF, Pedreros DH, Verdin JP, Rowland JD, Romero BE, Husak GJ, Michaelsen JC, Verdin AP (2014) A quasi-global precipitation time series for drought monitoring. U.S. Geological Survey Data Series 832, p. 4

Gardelle J, Hiernaux P, Kergoat L, Grippa M (2010) Less rain, more water in ponds: a remote sensing study of the dynamics of surface waters from 1950 to present in pastoral Sahel (Gourma region, Mali). Hydrol Earth Syst Sci 14:309-324

Gohar LK, Lowe JA, Bernie D (2017) The impact of bias correction and model selection on passing temperature thresholds. J Geophys Res: Atmos 122:12,045-12,061

Golitzen KG, Andersen I, Dione O, Jarosewich-Holder M, Olivry J-C (2005) The Niger river basin: a vision for sustainable management, directions in development. Washington, DC: World Bank. (C) World Bank

Gringorten II (1963) A plotting rule for extreme probability paper. J Geophys Res 1896-1977(68):813-814

Hargreaves GH, Samani ZA (1985) Reference crop evapotranspiration from temperature. Appl Eng Agric 1:96-99

IPCC (2014) Climate Change 2014 - Impacts, adaptation and vulnerability: part B: regional aspects: working group II contribution to the IPCC fifth assessment report: Volume 2: Regional Aspects. Cambridge University Press, Cambridge

Jones DA, Moore RJ (1980) Simple channel flow routing model for real time use. IAHS AISH Publ:397-408

Kay AL, Jones DA (2012) Transient changes in flood frequency and timing in Britain under potential projections of climate change. Int J Climatol 32:489-502

Kendon EJ, Stratton RA, Tucker S, Marsham JH, Berthou S, Rowell DP, Senior CA (2019) Enhanced future changes in wet and dry extremes over Africa at convection-permitting scale. Nat Commun 10:1794

Klein Goldewijk K, Beusen A, Janssen P (2010) Long-term dynamic modeling of global population and built-up area in a spatially explicit way: HYDE 3.1. The Holocene 20:565-573

Klein Goldewijk K, Beusen A, van Drecht G, de Vos M (2011) The HYDE 3.1 spatially explicit database of human-induced global land-use change over the past 12,000 years. Glob Ecol Biogeogr 20:73-86

Kwakye SO, Bárdossy A (2020) Hydrological modelling in data-scarce catchments: Black Volta basin in West Africa. SN Appl Sci 2:628

Lange S (2018) Bias correction of surface downwelling longwave and shortwave radiation for the EWEMBI dataset. Earth Syst Dynam 9:627-645

Le Coz C, van de Giesen N (2020) Comparison of rainfall products over Sub-Saharan Africa. J Hydrometeorol 21:553-596

Lebel T, Ali A (2009) Recent trends in the Central and Western Sahel rainfall regime (1990-2007). J Hydrol 375:52-64

Leduc C, Favreau G, Schroeter P (2001) Long-term rise in a Sahelian water-table: the Continental Terminal in South-West Niger. J Hydrol 243:43-54

Lehner B, Verdin K, Jarvis A (2008) New global hydrography derived from spaceborne elevation data. EOS Trans Am Geophys Union 89:93-94

Mahé G, Olivry J-C (1999) Assessment of freshwater yields to the ocean along the intertropical Atlantic coast of Africa (1951-1989). C R Acad Sci Ser IIA Earth Planet Sci 328:621-626

Maraun D (2016) Bias correcting climate change simulations - a critical review. Curr Clim Change Rep 2:211-220

Maraun D, Shepherd TG, Widmann M, Zappa G, Walton D, Gutiérrez JM, Hagemann S, Richter I, Soares PMM, Hall A, Mearns LO (2017) Towards process-informed bias correction of climate change simulations. Nat Clim Chang 7:764-773

Martens B, Miralles DG, Lievens H, van der Schalie R, de Jeu RAM, Fernández-Prieto D, Beck HE, Dorigo WA, Verhoest NEC (2017) GLEAM v3: satellite-based land evaporation and root-zone soil moisture. Geosci Model Dev 10:1903-1925

Massuel S, Cappelaere B, Favreau G, Leduc C, Lebel T, Vischel T (2011) Integrated surface water-groundwater modelling in the context of increasing water reserves of a regional Sahelian aquifer. Hydrol Sci J 56:1242-1264

Meehl GA, Goddard L, Murphy J, Stouffer RJ, Boer G, Danabasoglu G, Dixon K, Giorgetta MA, Greene AM, Hawkins E, Hegerl G, Karoly D, Keenlyside N, Kimoto M, Kirtman B, Navarra A, Pulwarty R, Smith D, Stammer D, Stockdale T (2009) Decadal prediction. Bull Am Meteor Soc 90:1467-1486 
Messager ML, Lehner B, Grill G, Nedeva I, Schmitt O (2016) Estimating the volume and age of water stored in global lakes using a geo-statistical approach. Nat Commun 7:13603

Michelangeli P-A, Vrac M, Loukos H (2009) Probabilistic downscaling approaches: application to wind cumulative distribution functions. Geophys Res Lett 36:11

Monerie P-A, Wainwright CM, Sidibe M, Akinsanola AA (2020) Model uncertainties in climate change impacts on Sahel precipitation in ensembles of CMIP5 and CMIP6 simulations. Clim Dyn 55:1385-1401

Moore RJ (2007) The PDM rainfall-runoff model. Hydrol Earth Syst Sci 11:483-499

Moriasi DN, Gitau MW, Pai N (2015) Daggupati P (2015) Hydrologic and water quality models: performance measures and evaluation criteria. Trans ASABE 58(6):1763-1785

Nash JE, Sutcliffe JV (1970) River flow forecasting through conceptual models part I - a discussion of principles. J Hydrol 10:282-290

Nicholson SE (2013) The West African Sahel: a review of recent studies on the rainfall regime and its interannual variability. ISRN Meteorol 2013:453521

Niel H, Paturel J-E, Servat E (2003) Study of parameter stability of a lumped hydrologic model in a context of climatic variability. J Hydrol 278:213-230

Obeng-Ofori D (2018) Sustainable Hydropower in West Africa (Chapter: Introduction). Kabo-Bah A, Diji CJ (eds.). Academic Press, pp. xv-xviii.

Olivry J-C (2002) Synthèse des connaissances hydrologiques et potentiel en ressources en eau du fleuve Niger. World Bank, Niger Basin Authority, Provisional report, Niamey

Panthou G, Lebel T, Vischel T, Quantin G, Sane Y, Ba A, Ndiaye O, Diongue-Niang A, Diopkane M (2018) Rainfall intensification in tropical semi-arid regions: the Sahelian case. Environ Res Lett 13:064013

Paturel JE, Ouedraogo M, Mahe G, Servat E, Dezetter A, Ardoin S (2003) The influence of distributed input data on the hydrological modelling of monthly river flow regimes in West Africa. Hydrol Sci J 48:881-890

Peugeot C, Guichard F, Bock O, Bouniol D, Chong M, Boone A, Cappelaere B, Gosset M, Besson L, Lemaître Y, Séguis L, Zannou A, Galle S, Redelsperger J-L (2011) Mesoscale water cycle within the West African Monsoon. Atmos Sci Lett 12:45-50

Priestley CHB, Taylor RJ (1972) On the assessment of surface heat flux and evaporation using largescale parameters. Mon Weather Rev 100:81-92

Rameshwaran P, Bell VA, Davies HN, Kay AL (2021) Historical (1950-2005) and projected (20062099) hydrological model (HMF-WA) estimates of monthly mean and annual maximum river flows across West Africa driven by CMIP5 projected climate data. NERC EDS Environmental Information Data Centre. https://doi.org/10.5285/6429828f-6a06-4d2d-8f50-4910b18f7ff4

Ramirez-Villegas J, Challinor AJ, Thornton PK, Jarvis A (2013) Implications of regional improvement in global climate models for agricultural impact research. Environ Res Lett 8:024018

Ribeiro EB, Batjes NH, van Oostrum AJM (2018) World Soil Information Service (WoSIS) - towards the standardization and harmonization of world soil data. Procedures manual 2018, Report 2018/01, ISRIC-World Siol Information, Wageningen

Richard A, Galle S, Descloitres M, Cohard JM, Vandervaere JP, Séguis L, Peugeot C (2013) Interplay of riparian forest and groundwater in the hillslope hydrology of Sudanian West Africa (northern Benin). Hydrol Earth Syst Sci 17:5079-5096

Robson A, Reed D. (1999) Floord Estimation Handbook Vol. 3: Statistical Procedures for Flood Frequency Estimation; Institute of Hydrology: Wallingford, UK.

Roudier P, Ducharne A, Feyen L (2014) Climate change impacts on runoff in West Africa: a review. Hydrol Earth Syst Sci 18:2789-2801

Sanogo S, Fink AH, Omotosho JA, Ba A, Redl R, Ermert V (2015) Spatio-temporal characteristics of the recent rainfall recovery in West Africa. Int J Climatol 35:4589-4605

Sultan B, Gaetani M (2016) Agriculture in West Africa in the twenty-first century: climate change and impacts scenarios, and potential for adaptation. Front Plant Sci 7:1262

Ta S, Kouadio KY, Ali KE, Toualy E, Aman A, Yoroba F (2016) West Africa extreme rainfall events and large-scale ocean surface and atmospheric conditions in the Tropical Atlantic. Adv Meteorol 2016:1940456

Taylor CM, Belušić D, Guichard F, Parker DJ, Vischel T, Bock O, Harris PP, Janicot S, Klein C, Panthou G (2017) Frequency of extreme Sahelian storms tripled since 1982 in satellite observations. Nature 544:475

Taylor KE, Stouffer RJ, Meehl GA (2012) An overview of CMIP5 and the experiment design. Bull Am Meteor Soc 93:485-498 
Tazen F, Diarra A, Kabore RFW, Ibrahim B, Bologo Traoré M, Traoré K, Karambiri H (2019) Trends in flood events and their relationship to extreme rainfall in an urban area of Sahelian West Africa: The case study of Ouagadougou. Burkina Faso. J Flood Risk Manage 12:e12507

Thompson JR, Crawley A, Kingston DG (2017) Future river flows and flood extent in the Upper Niger and Inner Niger Delta: GCM-related uncertainty using the CMIP5 ensemble. Hydrol Sci J 62:2239-2265

Todzo S, Bichet A, Diedhiou A (2020) Intensification of the hydrological cycle expected in West Africa over the 21st century. Earth Syst Dynam 11:319-328

Toté C, Patricio D, Boogaard H, Van der Wijngaart R, Tarnavsky E, Funk C (2015) Evaluation of satellite rainfall estimates for drought and flood monitoring in Mozambique. Remote Sens 7(2):1758-1776

UN (2017) United Nations, Department of Economic and Social Affairs, Population Division. World Population Prospects: The 2017 Revision, DVD Edition

van Vuuren DP, Edmonds J, Kainuma M, Riahi K, Thomson A, Hibbard K, Hurtt GC, Kram T, Krey V, Lamarque J-F, Masui T, Meinshausen M, Nakicenovic N, Smith SJ, Rose SK (2011) The representative concentration pathways: an overview. Clim Change 109:5

Vischel T, Panthou G, Peyrillé P, Roehrig R, Quantin G, Lebel T, Wilcox C, Beucher F, Budiarti M (2019) Chapter 4 - precipitation extremes in the West African Sahel: recent evolution and physical mechanisms. In: Venugopal V, Sukhatme J, Murtugudde R, Roca R (eds) Tropical Extremes. Elsevier, pp 95-138

Wilcox C, Vischel T, Panthou G, Bodian A, Blanchet J, Descroix L, Quantin G, Cassé C, Tanimoun B, Kone S (2018) Trends in hydrological extremes in the Senegal and Niger Rivers. J Hydrol 566:531-545

Wu H, Kimball JS, Li H, Huang M, Leung LR, Adler RF (2012) A new global river network database for macroscale hydrologic modeling. Water Resour Res 48:9

Publisher's note Springer Nature remains neutral with regard to jurisdictional claims in published maps and institutional affiliations. 